\title{
Paleocene fishes from Palenque, Chiapas, southeastern Mexico
}

\author{
Jesús Alvarado-Ortega, Martha Cuevas-García, María del Pilar Melgarejo-Damián, \\ Kleyton Magno Cantalice, Abril Alaniz-Galvan, \\ Gisel Solano-Templos, and Bruno Andrés Than-Marchese
}

\begin{abstract}
This paper provides the first geological and paleontological data on two Mexican Paleocene fossil localities, the División del Norte and the Belisario Domínguez quarries, recently discovered near Palenque, State of Chiapas. Both are part of the marine outcrops previously known as the Tenejapa (toward the West) and the Lacandón formations (toward the East and in Guatemala). Since the limits of these formations remain unclear in the Palenque area, the geological association of these localities is referred to as the Paleocene Tenejapa-Lacandón Unit. The fossil fishes are particularly abundant and well preserved in these sites; they represent taxa previously known from Eocene localities around the world, whose strata were deposited under continental and marine conditions. This new assemblage is peculiar because it includes potential new species of Pycnodontiformes, Osteoglossiformes, Anguillifromes, Clupeiformes, and "serranids" that might expand their temporal and paleogeografical distribution worldwide and therefore become important elements to understand the evolution of these groups. These 63 my fish localities are the closest, temporally and geographically, sites to the Chicxulub Crater, a crater intimately associated to the Mass Extinction Event at the Cretaceous-Paleogene boundary (K/P). These newly localities represent an important paleontological scenario that will contribute to achieve a better understanding of the marine vertebrate communities throughout this important geological event.
\end{abstract}

Jesús Alvarado-Ortega. Instituto de Geología, Universidad Nacional Autónoma de México; Circuito de la Investigación S/N, Ciudad Universitaria, Coyoacán, D.F., 04510, Mexico; alvarado@geologia.unam.mx Martha Cuevas-García. Instituto Nacional de Antropología e Historia, Dirección de Registro Público de Monumentos y Zonas Arqueológicas. Instituto Nacional de Antropología e Historia. Av. Victoria 110, Copilco El Bajo, Mexico DF 04510, D.F, Mexico marcuevas_12@hotmail.com

María del Pilar Melgarejo-Damián. Posgrado en Ciencias Biológicas, Instituto de Geología, Universidad Nacional Autónoma de México; Circuito de la Investigación S/N, Ciudad Universitaria, Coyoacán, D.F., 04510, Mexico pilar_melgarejo@yahoo.com

Kleyton Magno Cantalice. Laboratório de Ictiologia Tempo e Espaço, Instituto de Biologia Roberto Alcântara Gomes, Universidade do Estado do Rio de Janeiro, Rio de Janeiro, 20550-900, Brazil kleytonbio@yahoo.com.br Abril Alaniz-Galvan. Posgrado en Ciencias Biológicas, Instituto de Geología, Universidad Nacional Autónoma de México; Circuito de la Investigación S/N, Ciudad Universitaria, Coyoacán, D.F., 04510, Mexico luneta_negra@yahoo.com.mx

Alvarado-Ortega, Jesús, Cuevas-García, Martha, Melgarejo-Damián, María del Pilar, Cantalice, Kleyton Magno, Alaniz-Galvan, Abril, Solano-Templos, Gisel, and Than-Marchese, Bruno Andrés. 2015. Paleocene fishes from Palenque, Chiapas, southeastern Mexico. Palaeontologia Electronica 18.2.39A: 1-22

palaeo-electronica.org/content/2015/1282-paleocene-fishes-from-palenque 
Gisel Solano-Templos. Posgrado en Ciencias Biológicas, Instituto de Geología, Universidad Nacional Autónoma de México; Circuito de la Investigación S/N, Ciudad Universitaria, Coyoacán, D.F., 04510, Mexico giselst@hotmail.com

Bruno Andrés Than-Marchese. Museo de Paleontología "Eliseo Palacios Aguilera", Instituto de Historia Natural y Ecología, Calzada de los Hombres llustres s/n, Colonia Centro, Tuxtla Gutiérrez, 29000, Chiapas, México bruthmar@gmail.com

Keywords: Paleocene; fossils; Palenque; Tenejapa; Chiapas; Mexico

Submission: 26 January 2015. Acceptance: 9 July 2015

\section{INTRODUCTION}

The present manuscript provides the first geological and paleontological report on two new Paleocene localities near Palenque, an emblematic Mayan archeological site located in the State of Chiapas, southeastern Mexico. These localities are formally presented here as Belisario Dominguez and División del Norte. Both quarries have proved to contain rich and diverse fossil assemblages, mainly comprised of fishes.

The first fossils recovered from Palenque were reported by Sapper (1894, 1896, 1899), who informed the occurrence of fish remains on the surface of a finely-grained limestone flagstone that once formed part of the architectural structure of Palenque. Fifty years later, Mülleried (1951, p. 210$211,224)$ provided a superficial description of two fossil-bearing rocks from this site, one of which was the sample previously taken by Sapper. In this sample, Mülleried recognized remains belonging to the fish Pycnodus Agassiz, 1833 and, despite his preliminar identification; he suggested an Eocene age for this flagstone in concordance with the geological occurrence of Pycnodus in Monte Bolca, Italy.

Subsequent field investigations in Palenque (Ruz-Lhuillier, 1959; Fernández, 1991; GonzálezCruz, 1993; Olivera-Carrasco, 1997; López Bravo et al., 2003; and Cuevas-García, 2008), led to the collection and identification of fossil shark teeth and stingray spines from different primary and secondary archaeological scenes (mortuary offerings, and building debris and ceremonial waste disposal sites, respectively), whose taxonomical affinities suggest a Neogene age. These findings also include two flagstones containing some complete teleost fishes similar to those of the early reports on Palenque. The first of these flagstones was used to cover the entrance of a tomb; the second one occupied an uncertain position within an architectural assemble of the city.
In 2008, a project aiming to determine the taxonomical and geological nature of the fossil fish remains found in this archeological site was launched (Cuevas-García and Alvarado-Ortega, 2009). The work team consisted of researchers and students from the Instituto Nacional de Antropología e Historia (INAH) and the Instituto de Geología, Universidad Nacional Autónoma de México (UNAM). As a result of this INAH-UNAM project, the fish remains and some nearly complete specimens recovered from Palenque were taxonomically identified as pycnodonts, percomorphs, and gonorynchiforms, as well as stingray spines and isolated shark teeth. Also, the geological units where these fossils had been collected by the Mayans were ultimately identified from surrounding areas (Cuevas-García and Alvarado-Ortega, 2009). However, the archeological significance of this material hinders further paleontological analyses on these particular fishes. Fortuitously, current investigation along newly discovered geological units in and around the Municipality of Palenque has led to the identification of rich Paleocene and Neogene fossil bearing strata. The present paper focuses on the recently discovered Paleocene localities hereby named Belisario Dominguez and División del Norte, near Palenque, Chiapas, Mexico (Figure 1).

\section{Geological Settings}

A goal of this manuscript is to describe the geology of the fossil bearing strata of the Belisario Domínguez and División del Norte quarries, as well as to support their inclusion within a formal geological unit; hence, the lithologic and paleontological features observed in these fossiliferous sites are compared to those of the formal units (formations) already described in Palenque and surroundings, which are described in the Mexican Stratigraphic Lexicon (SGM, 2014), in specialized literature, and in the maps cited throughout the present text (Servicio Geológico Mexicano 2006a, 2006b). 


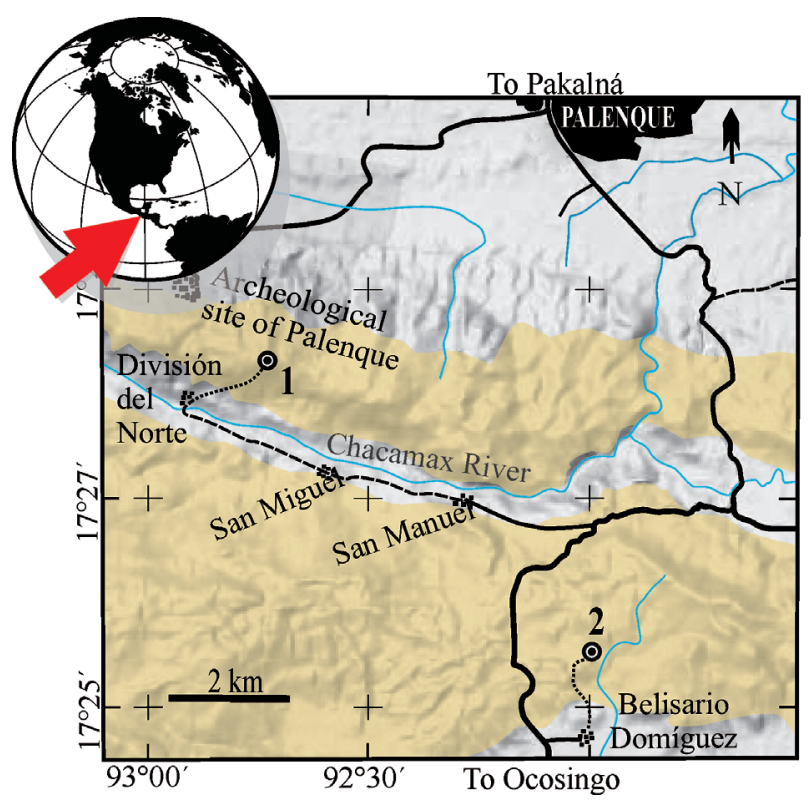

FIGURE 1. Map of the vicinity of Palenque including División del Norte and Belisario Domínguez quarries. The yellow areas show the outcrops of Paleocene marine strata identified here as Tenejapa-Lacandón unit (based on Servicio Geológico Mexicano, 2006a, 2006b).

The fossils studied in this manuscript come from two localities recently identified in the middle of the jungle within the Palenque Municipality, Chiapas, southeastern Mexico. These localities are herein formally named as the División del Norte and Belisario Domínguez quarries, respectively (Figure 1). Both localities are particularly small outcrops where flagstones are sporadically extracted with commercial purposes. The handcraft methods used in the collection of the fossils in these quarries result in minimal damage to the specimens (Figures 2-8); many of which are remarkably well preserved as well as engaging.

The División del Norte quarry is located between the coordinates $17^{\circ} 16^{\prime} 12.17^{\prime \prime} \mathrm{N}$ and $97^{\circ} 40^{\prime} 40.7^{\prime \prime W}, 5 \mathrm{~km}$ southeast from the downtown of the city of Palenque, approximately $2.3 \mathrm{~km}$ southeast from the archaeological site of Palenque, and about $1.2 \mathrm{~km}$ north from the División del Norte village, which is set in the northern side of the Chacamax River. There are at least four interconnected extraction sites in this locality, so scarcely exploited that they hardly go beyond the upper level of the bedrock. The foremost of these sites is a $3 \mathrm{~m}$ long and $2 \mathrm{~m}$ wide opening, with a depth of barely 3-4 m; its upper strata are vastly weathered and under the process of soil formation. However the rocks below are well preserved. The strata in this locality are finely laminated, yellow to beige, poorly carbonated clays, dolomites, and limestones that form a sequence between 5 and $15 \mathrm{~cm}$ in thickness. Its bedding planes show microturbidites, bioturbations, and numerous cylindrical (5-30 mm in length) phosphatized fecal pellets probably produced by the fishes, as well as exceptionally frail carbonized plant or algae remains. After the microscopic analysis of thin sections of fossil fish bearing strata from this site, microfossils have not yet been recovered in this unit. The parallel arrangement of these strata is altered by the presence of scarce spherical carbonate enriched nodules with diameters ranging between a few centimeters and up to 10 $\mathrm{cm}$. The upper and lower limits of this geological unit remain unknown due to the dense forest and deep soils observed in the División del Norte quarry as well as by its low depth.

The Belisario Domínguez quarry is located at approximately $9.5 \mathrm{~km}$ south of the downtown of Palenque city and $2 \mathrm{~km}$ northeast from the Belisario Domínguez village, between the coordinates $17^{\circ} 25^{\prime} 28.60 " \mathrm{~N}$ and $91^{\circ} 58^{\prime} 46.80 \mathrm{~W} \mathrm{~W}$. In this site, the extraction of flagstone is a recently initiated activity; subsequently, the depth of the quarry has hardly exceeded the soil level. On the whole, the lithology of this locality resembles that of the División del Norte quarry, with the exception that nodules are not present in Belisario Domínguez.

According to recently published Servicio Geológico Mexicano maps (Servicio Geológico Mexicano, 2006a, 2006b), the División del Norte and Belisario Domínguez quarries correspond to 
outcrops from the Tenejapa Formation, a formation previously described by Quezada (1987) near the San Cristóbal de las Casas town. Nevertheless, the Léxico Estratigráfico de México, a document also published by the Servicio Geológico Mexicano (Servicio Geológico Mexicano, 2014), implies that these outcrops might as well be part of the Lacandón Formation, a unit whose description (Vinson, 1962) was based on the study of a southward outcrop in Petén, Guatemala. As a matter of fact, both the Tenejapa and the Lacandón formations, two contemporary and laterally continuous structures, are mapped as a single unit in the SGM maps and correspond with the "Paleocene Series of Chiapas" firstly reported by González (1965). The geological paleoenviroment of this sedimentary series has been identified as a marine platform, which in the west was characterized by influential external conditions that led to the sedimentation of the Tenejapa Formation and in the east by primarily internal conditions in a shallow environment that resulted in the deposition of the Lacandón Formation (Quezada, 1987).

The lack of index microfossils and the occurrence of exceptionally narrow strata sequences from both the División del Norte and the Belisario Domínguez quarries make a formal geological identification of these sites currently unattainable. However, and as mentioned above, their geographical position within previously mapped Paleocene marine sedimentary strata nearby Palenque suggests that these localities are likely to be part of the Lacandón-Tenejapa unit. In addition, an early study on stable strontium isotopes $\left({ }^{87} \mathrm{Sr} /{ }^{86} \mathrm{Sr}\right)$ on pycnodont teeth from both localities (Cuevas-Garcia and Alvarado-Ortega, 2009) indicated an age of $63 \pm 1.5$ m.y., confirming a Paleocene origin (Early Paleocene: Danian).

Although the strata exploited in these two fossil localities do not present bands or nodules of gray to black flint as those documented from the Tenejapa Formation, the authors have observed dark-gray bands in some non fossiliferous quarries near Palenque and some calcareous nodules along the sequence exploited in the Division del Norte quarry (Figure 2).

The acknowledgment of these two fossiliferous sites as outcrops belonging to either the Lacandón or the Tenejapa formations is a geological matter that surpasses the objective of the present work. Their temporal and geographic boundaries must be established, their distinctive lithological characteristics need to be determined, and their identity as individual units or parts of a single formation is yet to be resolved.

Palenque is situated in the northern area of the Reverse Fault province defined by MenesesRocha (2001), which is equivalent to the tectonic provinces of Yaxchilán and Miramar (SánchezMontes de Oca, 1979). The sequence of the Aptian-Santonian limestones and dolomites of the Sierra Madre Formation includes the oldest outcrops in the Reverse Fault province (see Steele, 1986; Waite, 1986; Alvarado-Ortega and Than Marchese, 2012). The Campanian-Maastrichthian limestones of the La Angostura Formation overlie the Sierra Madre strata (Meneses-Rocha, 2001; Servicio Geológico Mexicano, 2006a, 2006b, 2014). Three Paleocene formations unconformably cover the Cretaceous strata in this province; in the south the calcareous breccias and shales of the Soyaló Formation are present; meanwhile, in the center and north of this province are present the limestones and dolomites belonging to the Lacandón andTenejapa and formations (the TenejapaLacandón Unit of this paper unit). Similarly, there are two Eocene formations uncormormely covering the Paleocene strata; one represented with the alternating sandstones and shales of El Bosque Formation, and the other, with the limestone and sandstone of the Lomot Formation. Although different authors note that the shales, limestones, and carbonate of Tulija Formation of Miocene age unconformably overlying the previous units (e.g., Meneses-Rocha, 2001); recently, the INAHUNAM research team mentioned here discovered, near Estrella de Belén village into the present studied area, a carbon-rich sequence of sands containing invertebrates and amber that suggest they are coeval with the famous Oligocene-Miocene amber strata of the Somojovel region.

All fossils recovered from the Division del Norte and the Belisario Dominguez quarries are preserved in marl interstratification surfaces. Most specimens are significantly compressed; however, some others show three-dimensional characteristics. Plant remains from both localities are poorlydefined carbonaceous impressions that might represent either vascular plants or algae. Particularly, some plant remains from División del Norte appear to be conifer-like. The occurrence of numerous small coprolites is common in Belisario Dominguez and rather scarce in División del Norte.

Marl strata from División del Norte, Belisario Domínguez, and other non-fossil bearing quarries show an exceptionally fine texture, although they are somewhat enriched with calcium carbonates. 


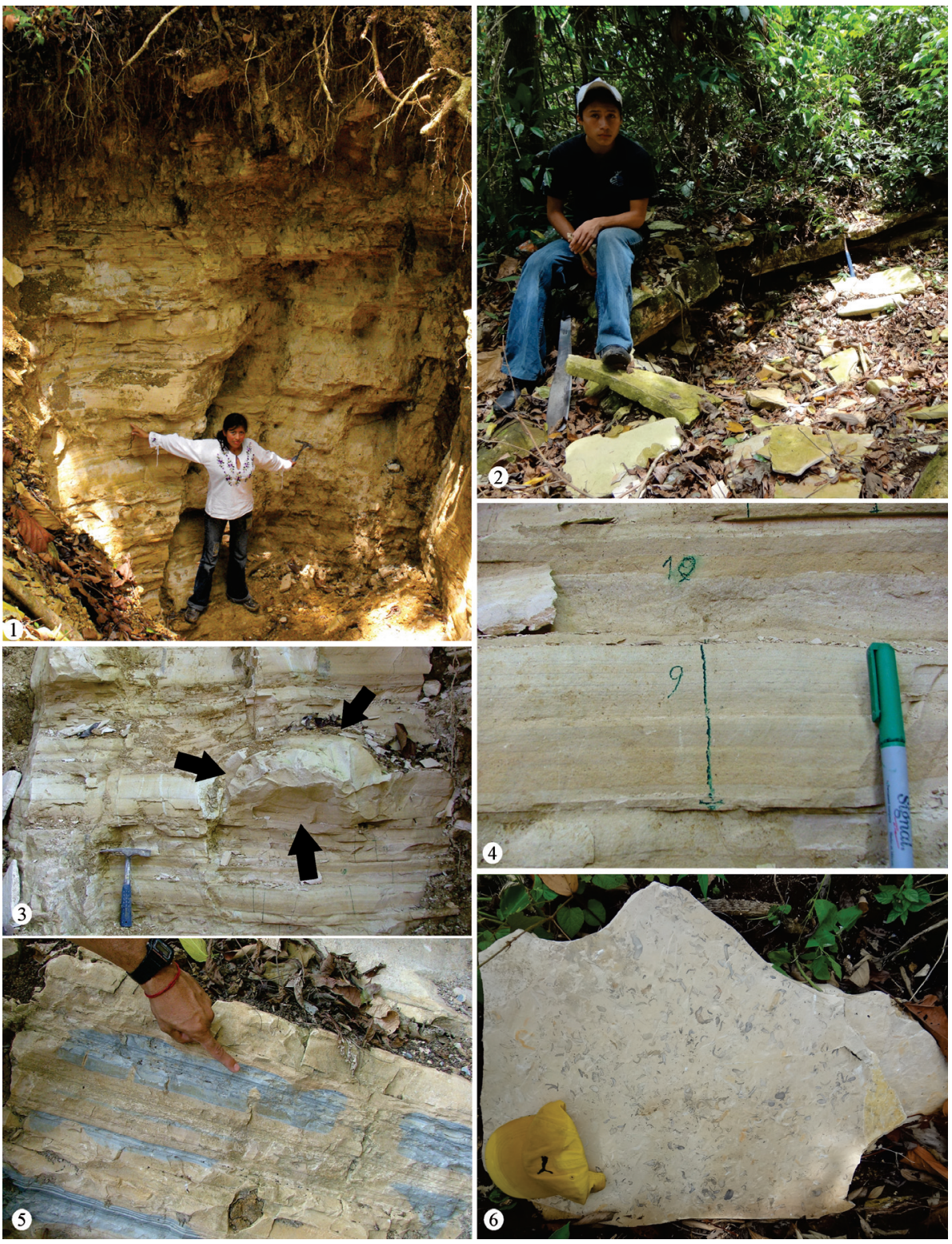

FIGURE 2. General views of the División del Norte (1) and Belisario Domínguez quarries (2). 3, A nodule in situ at División del Norte (between the black arrows). 4, Strata laminated in Belisario Domínguez quarry. 5, Gray silicified bands within the marl strata in a Paleocene non fossiliferous quarry near Palenque. 6, Plant or algae remains remains of Belisario Domínguez quarry.

For this reason, replicas of representative Mayan art reliefs discovered in the nearby archeological site are presently carved in this type of rock and offered for sale in downtown Palenque; local artisans prefer the less carbonated and therefore softer flagstones. Occasionally, fossils are included in relief replicas as an additional artistic element, and it is possible that some otherwise valuable fossil fish specimens are deposited in domestic and international private collections (Cuevas-García and Alvarado-Ortega, 2009).
Often, fishes preserved in the upper strata of these two new localities are badly preserved, their bones have dissolved and specimens can be frequently appreciated as merely faint impressions. On the other hand, fishes collected from deeper strata might preserve not only complete bones, but also phosphatized soft tissues as in the most renowned Konservat-Lagertätten localities worldwide (e.g., Alvarado-Ortega et al., 2007); their abdominal cavities and other crevices are saturated with whitish masses of phosphates. Although 

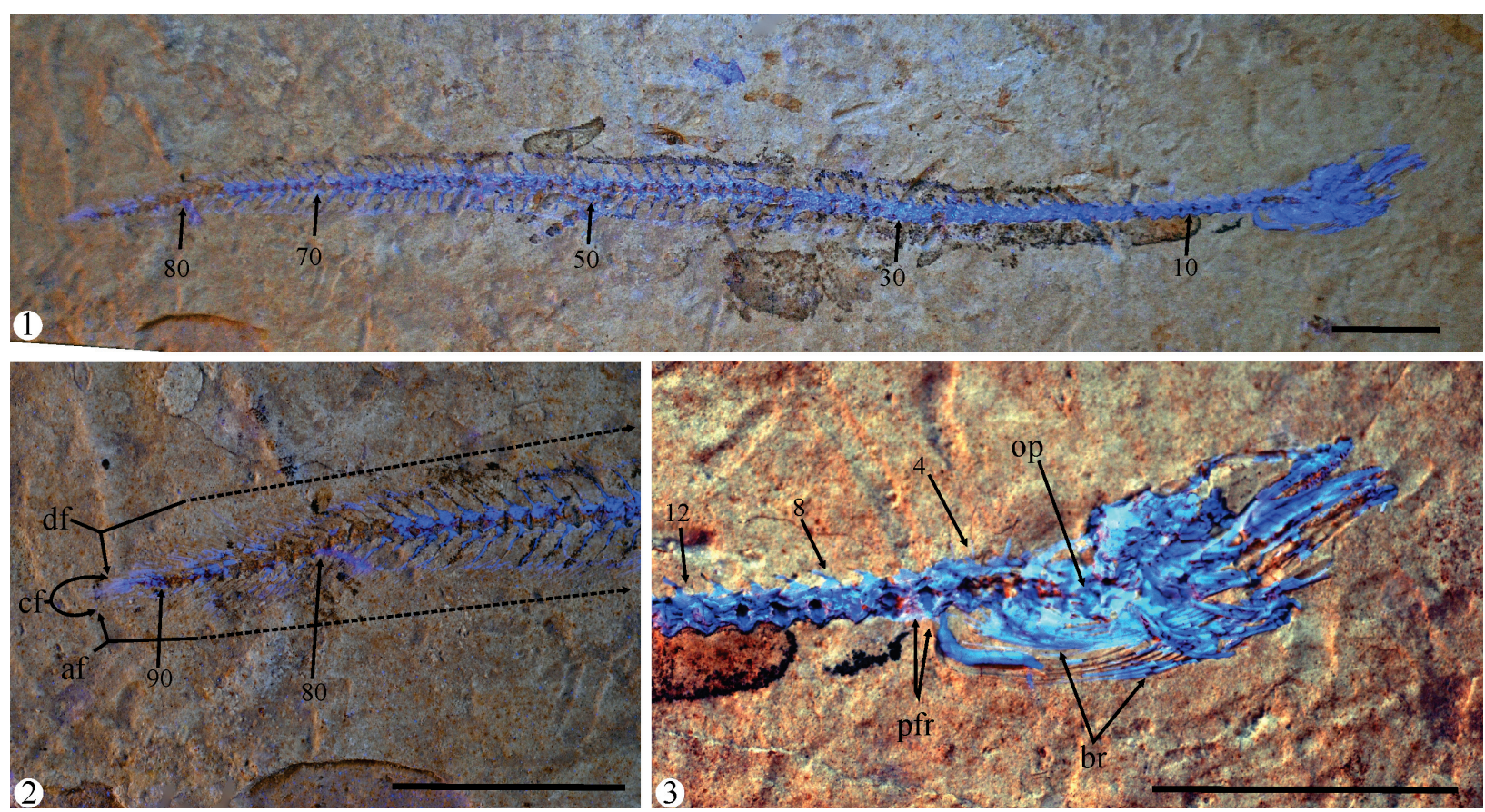

FIGURE 3. 1, General view of the specimen IGM 4547, an anguilliform fish from the Paleocene marine strata at Belisario Domínguez quarry, Municipality of Palenque, Chiapas, Mexico. 2, Close up of the posterior part of the trunk and caudal fin. 3, Close-up of the region of the head and anterior part of the trunk. Scale bars equal $10 \mathrm{~mm}$. Abbreviations: af, anal fin; br, branchistegal rays; cf, caudal fin; df, dorsal fin; op, opercle; pfr, pectoral fin rays; numbers show the position of each vertebrae.

an assessment of the quality of preservation and fish diversity of these localities is still required, it can be stated that the División del Norte and the Belisario Dominguez quarries may represent one of the exceptional fossil conservation sites that exist globally.

\section{MATERIAL AND METHODS}

The main goal of this paper is to provide a general view of the fish diversity collected in both the Belisario Dominguez and the División del Norte quarries. It is worth mentioning that although the taxonomic advances so far achieved are indicated, this work is not an exhaustive anatomical, taxonomic, or systematic study.

The taxonomic determinations of the fossils here documented were obtained by way of updated specialized references. The anatomical details of the specimens herein documented were observed under white and UV light as indicated in the respective figure captions. The anatomical abbreviations used here are described in the captions of the corresponding figures.

The specimens collected from these localities are currently deposited in the Colección Nacional de Paleontología (IGM) UNAM, the Palenque local INAH Museum, and the Museo de Paleontología "Eliseo Palacios Aguilera" (IHNFG), Tuxtla Gutiérrez, Chiapas, Mexico. All specimens referred to and illustrated here were mechanically prepared. When necessary, osteological structures were uncovered by means of micro-air-excavators and odontological needles under a stereoscopic microscope. Specimens were hardened with plexygum.

The taxonomic identity of the fossils discussed in the systematic paleontology section is the result of general comparative exercises rather than comprehensive descriptive and comparative analyses. Although some characteristics identified here suggest the presence of potentially new taxa, a future and more comprehensive analysis to confirm these observations requires to be developed.

\section{RESULTS}

\section{Systematic Paleontology}

Order ANGUILLIFORMES Goodrich, 1909

Family indeterminate

Genus and species indeterminate 
Referred Material. IGM 4547 (Figure 3.1-3.3), complete specimen lacking the posterior part of the tail, and with an estimated total length (TL) of $118.37 \mathrm{~mm}$. IHNFG-4891, complete specimen with an estimated TL of $135 \mathrm{~mm}$; IHNFG-4893 and IHNFG-4894, two complete specimens preserved in the same flagstone and both measuring $135 \mathrm{~mm}$ of TL. All specimens were recovered from the Belisario Domínguez quarry (i.e., Locality-IGM 3870).

Remarks and comparison. Elopomorpha is a natural clade that has been divided into three to five orders, including Albuliformes, Anguilliformes, Elopiformes, Notacanthiformes, and Saccopharyngiformes (e.g., Greenwood et al., 1966; Inoue et al., 2001; Nelson; 2006; Wiley and Johnson, 2009). The morphological specializations of the most derived of the elopomorph orders, Anguilliformes and Saccopharyngiformes, have led to controversial interpretations that have therefore hindered the establishment of a robust and consensual classification. Forey et al. (1996) were the first authors to recognize both orders as part of a monophyletic group, a proposal supported by recent studies (Santini et al., 2013; Chen et al., 2014).

The specimens referred in the present work are recognized as true Anguilliformes, commonly known as eels, because their long and cylindrical snake-like bodies, their absence of a pelvic fin, and their pectoral fin located in the middle of the trunk far from the ventral border and behind the fourth vertebra (Figure 3.1) are distinctive characters of this order (Nelson, 2006; Wiley and Johnson, 2009; Johnson et al., 2011; Chen et al., 2014). Additionally, the Belisario Domínguez eels cannot belong in the Saccopharyngiformes since the latter is a group of highly specialized fishes lacking their opercular bones and branchiostegal rays, whereas in the Mexican specimens such bones are present (Figure 3.3).

Although the origin of eels dates back to the Cenomanian (Forey et al., 1996), their fossil record is scarce and the knowledge on the morphology of a large number of living eels is limited. Therefore, it is not presently feasible to classify Cretaceous eels within families solely created to include their Cenozoic and extant relatives. At the beginning of the present decade, Johnson et al. (2011) described Protoanguilla palau, a species which was placed in its own family, Protoanguillidae, as a putative living sister group of both Cenozoic and extant eels. However, succeeding studies (Santini et al., 2013; Chen et al., 2014) identified this species at the base of the living eels as the sister group of the family Synaphobranchidae. In this paper, we follow the comparative exercise of Johnson et al. (2011) as a template to analyze the Paleocene eels recovered from the Belisario Domínguez quarry.

The Belisario Domínguez specimens, like most eels (with the exception of the "saccopharyngiforms"), present a rostrocaudally elongated opercle with a bottle-neck articular condyle. Moreover, these Mexican fossils share the following characteristics with all extant eel taxa (Figure 3): 1) scaleless bodies and, when present, scales are unimbricated; 2) absence of endopterygoid (not illustrated in this work); 3) long dorsal and anal fins confluent with caudal fin; and 4) less than eight rays in each caudal fin lobe. In contrast, Cretaceous eels exhibit scales and an endopterygoid, and their dorsal and anal fins are clearly separated from a caudal fin with at least eight rays in each lobe (see Johnson et al., 2011, p. 6). In addition, the number of total vertebrae in extant and most Cretaceous eels ranges between 98 and over 300, in Protoanguilla it varies between 79 and 87 , and in some saccopharyngiform eels this number is reduced to 70 . The number of total vertebrae in these Mexican fossils ranges between 92 and 93, which lies in the 90 to 95 range of Luenchelys Belouze et al., 2003, a primitive anguillifrom of uncertain affinities from the Cenomanian marine deposits of Namoura, Lebanon. This characteristic makes Luenchelys and these Mexican fossils eels different from practically all the other eels.

As mentioned above, the fossil record of eels is scarce and rarely includes complete skeletons (Daniltshenko, 1964; Wiley and Stewart, 1981; Forey et al., 2003). The Cenozoic specimens are extremely scarce; these are known from the Upper Paleocene strata of the Danata Formation in Turkmenistan; the renowned Eocene marine quarries of Monte Bolca, Italy (Blot, 1984; Sytchevskaya and Prokofiev, 2004); as well as the Middle Eocene freshwater strata of Messel, Germany, where the oldest representative of the genus Anguilla Shaw, 1803, was collected and named as Anguilla ignota by Micklich, 1985.

In this matter, the Palenque eels collected from the Belisario Domínguez quarry present a major opportunity to extensively study this group, since they are the fourth Paleogene record of eels worldwide and the first Paleocene eel of America, and their intermediate affinities between Cretaceous and Modern eels are hitherto unique.

Order CLUPEIFORMES sensu Grande, 1985 Suborder CLUPEOIDEI sensu Grande, 1985 

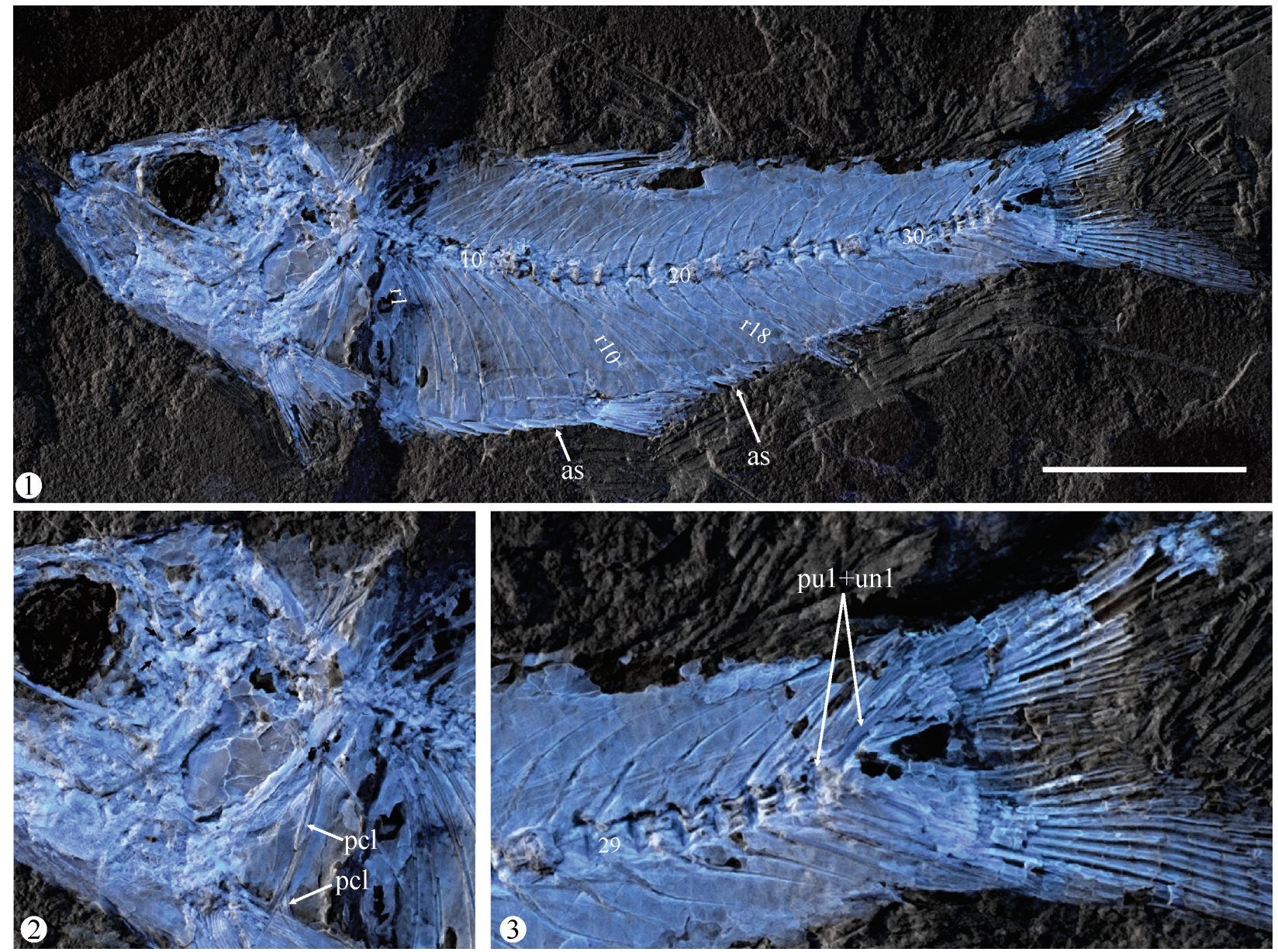

FIGURE 4. 1, General view of the specimen IGM 4548, a clupeid from the Paleocene marine strata at División del Norte, Municipality of Palenque, Chiapas, Mexico. 2, Close-up of the pectoral girdle. 3, Close-up of the caudal region. Abbreviations: as, abdominal scutes; pcl, posclethra; pu1+un1, pural centra 1 and uroneural 1 fused to each other; numbers show the position of ribs and vertebrae. Scale bar equals $10 \mathrm{~mm}$.

Family CLUPEIDAE Cuvier, 1817

Genus and species indeterminate

Referred Material. IGM 4548 (Figure 4), complete specimen from the the División del Norte quarry (i.e., Locality-IGM 3869); standard length $38.5 \mathrm{~mm}$. Remarks and comparison. The family Clupeidae belongs in the order Clupeiformes, a taxon that along with the order Ellimmichthyiformes constitute the teleostean cohort Clupeomorpha. Because the comprehensive analysis on extant and extinct Clupeomorpha developed by Grande (1985) has proven to be robust and predictive throughout nearly 30 years (see Alvarado-Ortega, 2014), it has been taken as a reference in the study of the División del Norte clupeomorph. From such evaluation, it was possible to recognize various diagnostic characteristics that support the inclusion of IGM 4548 within the family Clupeidae (Figure 4).
On the one hand, IGM 4548 shows the single indisputable synapomorphy of the Clupeomorpha clade, the presence of a series of abdominal scutes. This specimen also shows the presence of recessus lateralis, an intracranial space in the otic region of the skull where the supraorbital, infraorbital, preopercular, and temporal sensory canals open and which is diagnostic of the order Clupeiformes. Additionally, IGM 4548 exhibits at least two of the diagnostic features of the suborder Clupeoidei (Grande, 1985, p. 258-259), the loss of the lateral line and the fusion of the first uroneural with the first preural centrum.

Grande (1985, figure 9) suggested that the suborder Clupeoidei is divided into three main groups or superfamilies, Clupeoidea, Engrauloidea, and Pristigasteroidea. Clupeoidea differs from the other two superfamilies and most species in the Clupeomorph basal groups (e.g., Ellimmich- 


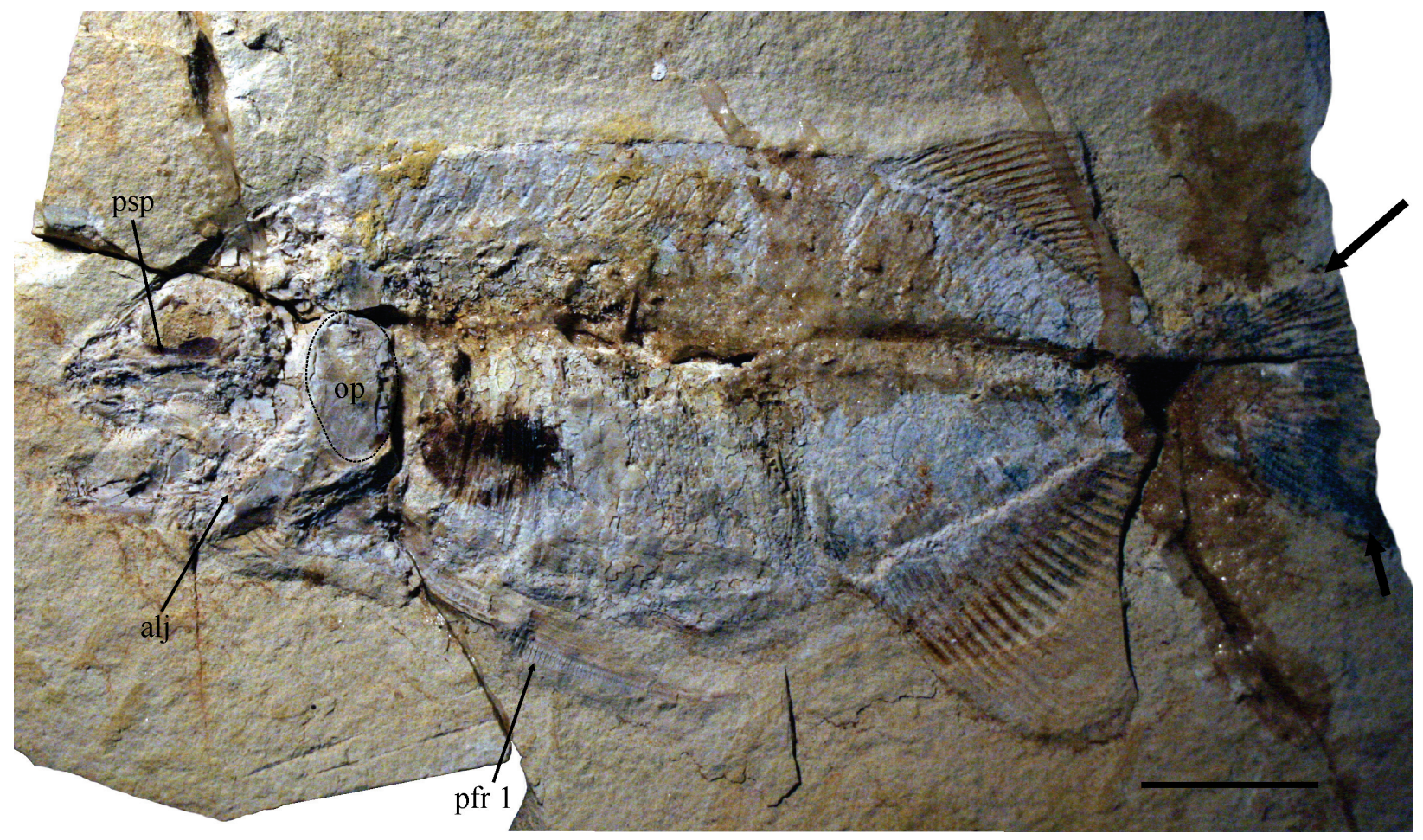

FIGURE 5. Specimen IGM 4549, Phareodus sp. from the Paleocene marine strata of División del Norte quarry, Municipality of Palenque, Chiapas, Mexico. Scale bar equals $20 \mathrm{~mm}$. Abbreviations: alj, articulation of lower jaw; op, opercle; pfr 1, first pectoral fin ray; psp, parasphenoid; arrows in the tail enclose the caudal principal fin rays.

thyiformes) in that it tends to develop larger abdominal areas, associated with an increase in the number of pleural ribs/number of preural vertebrae ratio (PR/PV). IGM 4548, displays 18 ribs and 37 or 38 vertebrae, i.e., it presents a PR/PV ratio of 0.48 or 0.47 . And, although it overlaps with the ranges of Ellimmichthyiformes (0.37-0.56) and two suborders of Clupeiformes, Engrauloidea (0.270.51 ) and Clupeoidea (0.49-0.74), it helps to differenciate IGM 4548 from some other clupeomorph groups with either lower or higher PR/PV ratios such as Pristigasteroidea (0.28-0.44), Denticipitoidei $(0.37-0.40)$, Alosinae $(0.50-0.63)$, Clupeinae (0.52-0.63), Chirocentridae (0.59), and Dusumeeriinae (0.58-0.74). Moreover, IGM 4548 shows two large rodlike poscleithra, a diagnostic character that supports its inclusion within the family Clupeidae, superfamily Clupeoidea.

Currently, GST is developing an extensive work on the description and affinities of the Paleocene clupeids of Palenque. However, two important notions can derive from the present work, 1) the fossil record of the family Clupeidae has extended further in time; prior to this paper, the oldest evidence of this family dated back to the Eocene (Gaudant, 1991), and 2) since a number of interrelationships of the clupeid fishes is still uncertain (Grande, 1985), the study of these Mexican fishes might provide new data to contribute to the creation of new and more comprehensive phylogenetic hypotheses of this family.

Order OSTEOGLOSSIFORMES Greenwood et al., 1966

Family OSTEOGLOSSIDAE Bonaparte, 1832 Subfamily OSTEOGLOSSINAE Bonaparte, 1832 Genus PHAREODUS Leidy, 1873 Phareodus sp.

Referred Material. IGM 4549 (Figure 5), complete specimen from the División del Norte quarry (i.e., Locality-IGM 3869). This specimen lacks the posterior part of the tail and its estimated standard length is $145 \mathrm{~mm}$.

Remarks and comparison. Recent phylogenetic analyses published by Wilson and Murray (2008), Zhang (2006), and Hilton (2003), have proved that Osteoglossomorpha and Osteoglossiformes are natural groups. Osteoglossomorpha is a teleostean group with a diagnostic relatively low number of principal caudal fin rays (18); a trend in the reduction in the number of rays in this group is present even in the most derived groups. The 17 principal 
fin rays present in the caudal fin of IGM 4549 (ordered in the formula $\mathrm{i}-8+7-\mathrm{i}$ ) support its inclusion within Osteoglossomorpha and Osteoglossiformes (e.g., Nelson, 1969; Li et al., 1997).Other important synapomorphies that characterize these taxa and primarily support their naturalness are mainly related to the caudal skeleton, lower jaw, circumorbital bones, and gill and hyoid arches (also see Wiley and Johnson, 2009, p. 132-134). Unfortunately, IGM 4549 does not appear to present them.

The family Osteoglossidae sensu Wilson and Murray (2008) is partially defined by the position of the lower jaw-quadrate articulation, behind the posterior level of the orbit. Among osteoglossomorphs, this condition is present exclusively in the Chinese genus Xixiaichthys Zhang, 2004. In other osteoglossomorphs, this articulation is located in a forward position. Although in IGM 4549 the horizontal limb of preopercle is partially covering the articulation of the lower jaw, the latter is clearly placed forward, as in most osteoglossids.

Among osteoglossids, only the genus Phareodus presents the following assortment of characters: an exposed scale area entirely covered with reticulate furrows, an opercle depth/width ratio of approximately two or greater, a greatly enlarged and unusually long first pectoral fin ray, a toothless parasphenoid, and a rounded opercle, narrower than its middle-upper point ventral border (Wilson and Murray, 2008, characters 72(2), 33(1), 61(1), $8(0), 87(1)$, respectively). The presence of all the above characters in specimen IGM 4549 suggests its identification as a member of the genus Phareodus.

In a comparative analysis of Phareodus, Li et al. (1997) claim that this genus comprises two North American species from the Green River Formation, $P$. encaustus (Cope, 1871) and $P$. testis (Cope, 1877), as well as an Australian one, $P$. queenslandicus Hills, 1934, from the Redbank Plains Formation of southern Queensland, Australia. They also suggest that Brychaetus muelleri Woodward, 1901, from the Eocene London Clay strata is in fact a member of the genus Phareodus. Along with Asian species $P$. songziensis Zhang, 2003 from the Yangxi Formation of China, all species mentioned above share an Eocene age and a freshwater origin, with the exception of $P$. muelleri, which probably presented marine habits. Hence, regarding the distribution of these species, two possible biogeographical scenarios can explain their wide distribution in different continents. The first possibility is that this genus comprises a long history, and its distribution during the Eocene was closely linked to the hydrological history of each continent. The second alternative is that marine representatives of Phaerodus reached different continents across the seas.

It is early to say whether IGM 4549 is a marine Phareodus representative or a freshwater one that was dragged and deposited in the sea. However and regardless its environment, this Paleocene Mexican osteoglossomorph is the oldest Phaerodus so far discovered and therefore a specimen to consider in future attempts to understand the osteoglossiform paleobiogeography.

IGM 4549 shows a number of meristic differences with the previously reviewed nominal species of Phaerodus (Li et al., 1997; Zhang, 2003) and may represent a new species. Nevertheless, a comprehensive descriptive study is necessary to confirm the above and is in fact currently in progress.

\section{Order PERCIFORMES Bleeker, 1859 (sensu Patterson, 1964)}

Suborder PERCOIDEI sensu Bleeker, 1859 (sensu Nelson, 2006)

Family "SERRANIDAE" Swainson, 1839 Genus and species indeterminate

Referred Material. IGM 4550 (Figure 6), specimen from the División del Norte quarry (= Locality-IGM 3869). This specimen has an estimated standard length of $69 \mathrm{~mm}$ and lacks the caudal fin.

Remarks and comparison. IGM 4550 was previously described by Alaniz-Galvan (2011) and temporarily catalogued as JAO 70 . At present, additional specimens from both the División del Norte and Belisario Domínguez quarries are being collected. A further analysis of all the above will contribute to an extensive descriptive and taxonomic study of the serranids in the surroundings of Palenque.

The Percomopha series was firstly recognized by Rosen (1973) and recently renamed as Percomorphacea by Wiley and Johnson (2009). Proposed by Stiassny and Moore (1992), the naturalness of the group is based on two shared characteristics: a pelvic fin located below the pectoral fin, and an association between both pectoral and pelvic girdles (including ligamentous attachments, which are hardly preserved in the fossil record). Both characteristics are present in specimen IGM 4550 (Figure 6). A number of other authors (Johnson and Patterson, 1993; Patterson and Johnson, 1995, p. 4; Wiley and Johnson, 2009) have recognized the occurrence of six or fewer rays in the pelvic fin as an additional diagnostic characteristic of the percomophs. 


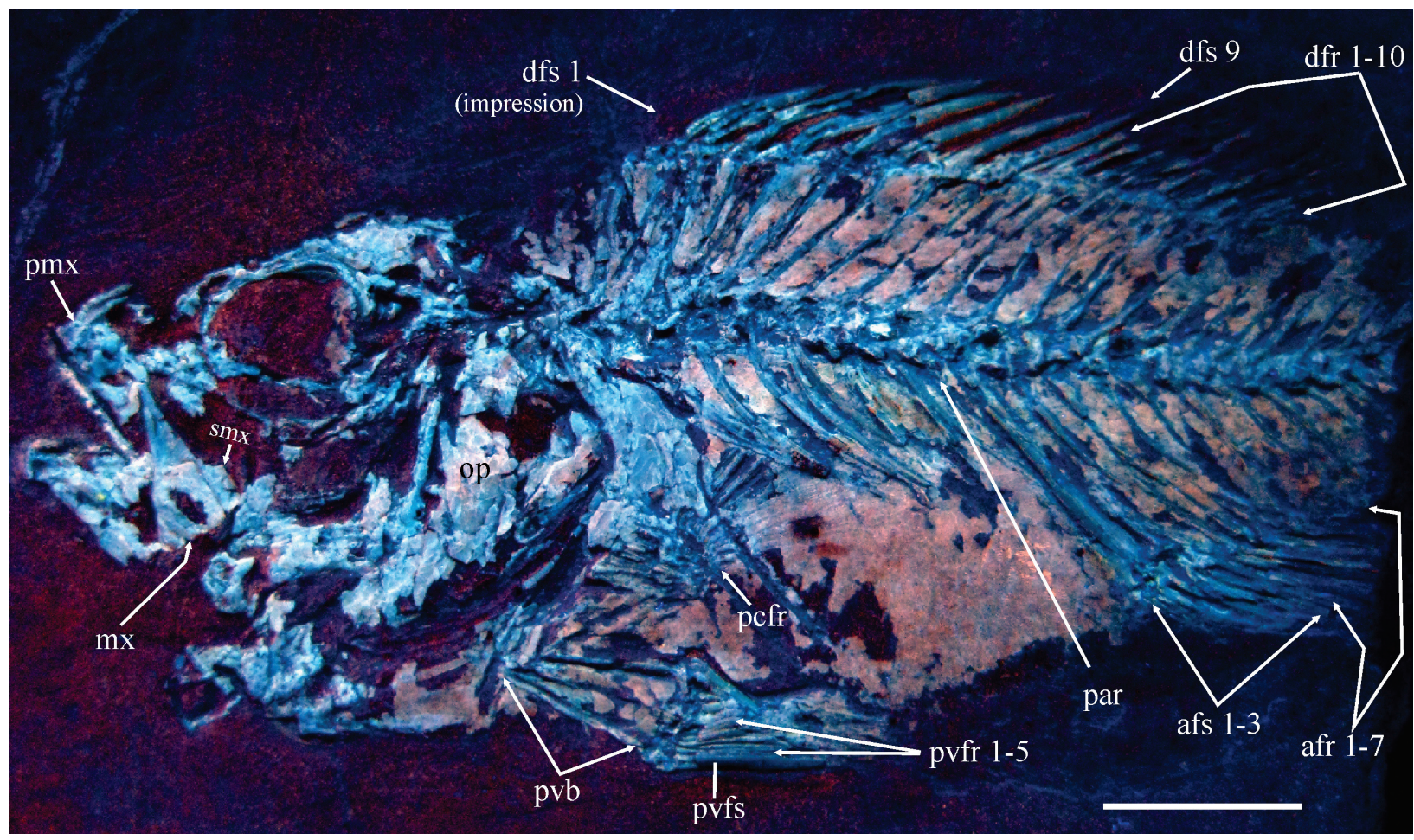

FIGURE 6. Specimen IGM 4550, a "Serranidae" fish from the Paleocene marine strata at División del Norte quarry, Municipality of Palenque, Chiapas, Mexico. Scale bar equals $10 \mathrm{~mm}$. Abbreviations: afr, anal fin ray; afs, anal fin spine; dfr, dorsal fin rays; dfs, dorsal fin spine; mx, maxilla; op, opercle; par, parapophysis (in the vertebra 10); pcfr, pectoral fin rays; pmx, premaxilla; pvb, pelvic bone; pvfr, pelvic fin rays; pvfs, pectoral fin spine; smx, supramaxilla; numbers show the position of the vertebrae.

The relationships among Percomorphacea have been so controversial that the order Perciformes is presently considered an incertae sedis group within this Division (Wiley and Johnson, 2009). On the other hand, Patterson (1964, p. 466) considers that perciforms were derived from Beryciformes and have a number of distinctive characteristics. One of these characteristics is the reduction of the pelvic fin to one spine and only five rays (Figure 7 ), an attribute that can be easily observed in IGM 4550.

Moreover, Nelson (2006, p. 341) provided a list of diagnostic characteristics for the suborder Percoidei. Of these features (Figure 6), IGM 4550 exhibits the presence of anterior spines in the dorsal fin (which may be formed by one or two lobes), a ventral edge on the upper jaw only formed by the premaxilla; and vertebral column not associated with epipleurals and epicentral (intermuscular bones). Based upon this context, specimen IGM 4550 is considered a member of the suborder Percoidei.

The suborder Percoidei is considered the most diverse of all Perciformes (Nelson, 2006), with about 79 families, which are often diagnosed based on the body and fin shapes and some meristic features such as number of vertebrae, spines and fin rays. After comparing IGM 4550 to all 79 families, it can be inferred that this specimen belongs in the family Serranidae. IGM 4550, as other serranids, shows the following combination of characters (e.g., Nelson, 2006; Smith and Craig, 2007) (Figure 6): 1) The single dorsal fin is separated from the caudal fin; 2 ) the dorsal fin presents a notch at the middle of its length (in IGM 4550 this notch is formed because the dorsal spine 8 is shorter than the nearest; 3 ) the vertebral column includes 24 vertebrae. 4) The anal fin formula presents three spines and 6-12 rays (III+6-12) (IGM 4550 exhibits three spines and seven rays). 5) The dorsal fin formula includes $5-10$ spines and 11-32 rays $(V X+11-32)$. Although the nine spines of IGM 4550 follow this formula, its ten rays are just below the lower limit of this account; the study of additional specimens will clarify this uncertainty.

Swainson (1839) created the family Serranidae to include the genus Serranus Cuvier, 1817, and related forms; however, it quickly became a taxonomic "wastebasket group." Gosline (1968) included three subfamilies within Serranidae: Ser- 
raninae, Anthiinae, and Epinephelinae, which are mainly characterized by the presence of three spines on the operculum. Smith and Atz (1969) suggested the addition of a fourth serranid group, the subfamily Grammistinae. Although the opercle in IGM 4550 is poorly preserved, an evident spine can be distinguished.

The interrelationships of serranids, an extremely diverse group of basal perciforms, are problematic (e.g., Thomson et al, 1979; Johnson, 1983). Smith and Craig (2007) found no phylogenetic differences between Percoidei, Perciformes and Percomorpha; their results show that "percoids" are scattered all throughout Percomorpha. Although these authors regard the family Serranidae as unnatural, they proved the naturalness of the serranid subgroups by re-ranking them. Their family Epinephelidae includes the "epinephelins" and the "grammistins." In their analysis, Smith and Craig (2007) found that a number of "serranid" genera are intimately associated with the superfamily Notothenioidea, and that Serraninae, Trachininae, and Anthiinae are closely related to each other and therefore might constitute a natural family placed near the base of the Percomorpha. Considering the observations above and the comparative analysis on the arrangement of supraneurals and support structures of percoid dorsal fins developed by Kendall (1976), it is possible to categorize IGM 4550 as a likely member of the subfamily Serraninae (Figure 7). This Mexican fish presents three supraneurals that occupy the interneural spaces in a one to one order (the first supraneural is in front of the first neural spine and the second supraneural is between neural spines 1 and 2 . Its third supraneural and first dorsal pterygiophore occupy the interneural space between neural spines 2 and 3; its first dorsal pterygiophore is robust, with a wide longitudinal section and an articulation with the first two spines of the dorsal fin. In addition, its dorsal pterygiophores 2 and 3 are placed in the next interneural space (between the neural spines 3 and 4). This arrangement is similar to that described in the subfamily Serraninae by Kendall (1976, figure 1 ).

The record of putative perciforms includes fossils discovered in both Late Cretaceous and Paleogene localities (Patterson, 1964) (Table 1). The known perciform species to date are Eoserranus hislopi Woodward, 1908, described from skull and pectoral girdle fragments, from Eocene Lameta (Training Dongargaon), India, a species repeatedly identified as a serranid (Pondella et al., 2003; Arratia et al, 2004; Taverne, 2010); Proserra-
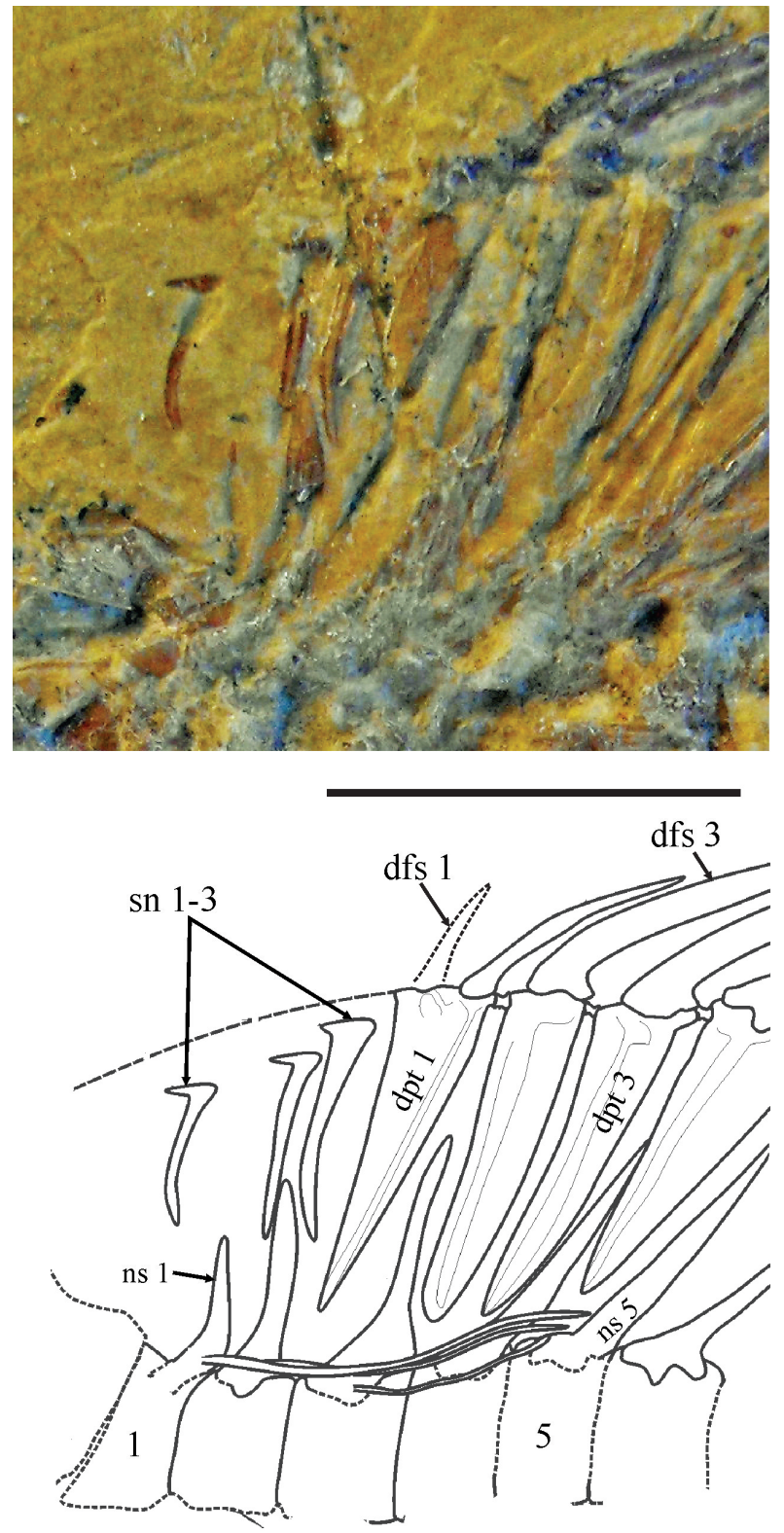

FIGURE 7. Close-up and line drawing of the anterior dorsal region of the body of IGM 4550, a "Serranidae" fish from the Paleocene marine strata at División del Norte quarry, Municipality of Palenque, Chiapas, Mexico. Scale bar equals $10 \mathrm{~mm}$. Abbreviations: dfs, dorsal fin spine; dpt, dorsal pterygiophopre; ns, neural spine; sn, supraneurals; numbers show the position of the vertebrae.

nus lundensis (Davis, 1890) from Paleocene sediments (Danian) from Limhamn, southern Sweden; Prolates heberti (Priem, 1899) from the Paleocene deposits of Mont Aimé, Chalons-sur-Marle, France; and Prolates dormaalensis (Casier, 1967), found in deposits in lower Eocene Dormaal, Belgium. Other species to be considered are the recently 
TABLE 1. Comparison the specimen IGM 4550 and other Cretaceous-Paleocene incertae sedis perciformes, blue areas enclose the characters shared by IGM 4550 and other fossil taxa/specimens. Abbreviations: abd, abdominal vertebrae; cau, caudal vertebrae; cic, cicloid scale; cte, ctenoid scale; smx, supramaxila (based on Alaniz-Galvan, 2011, table 6).

\begin{tabular}{|c|c|c|c|c|c|c|c|}
\hline & $\begin{array}{c}\text { Dorsal fin } \\
\text { formula }\end{array}$ & $\begin{array}{l}\text { Anal fin } \\
\text { formula }\end{array}$ & $\begin{array}{l}\text { Vertebrae } \\
\text { (abd+cau) }\end{array}$ & $\begin{array}{c}\text { Vertebrea } \\
\text { with } \\
\text { parapophysis }\end{array}$ & $\begin{array}{l}\text { Predorsal } \\
\text { Formula }\end{array}$ & $\begin{array}{l}\text { Scale } \\
\text { Type }\end{array}$ & smx \\
\hline $\begin{array}{l}\text { Percomorpha indet. } \\
\text { (Arratia et al., 2004) }\end{array}$ & $I X ?+4 ?$ & $?$ & $14 ?(8 ?+6 ?)$ & $6 ?(3-8 ?)$ & $?$ & cte & $?$ \\
\hline Nardoicthys & VI-VII+11-12 & $0+10$ & $25(11+14)$ & $6(6-11)$ & $\begin{array}{c}0 / / 0+0+1 / 1 / 1 / \\
\text { ó } \\
0 / 0 / 0+1 / 1 / 1\end{array}$ & cic & 0 \\
\hline Zornziperca & $\mathrm{VI}+11$ & $0+10$ & $25(11+14)$ & $6(7-12)$ & $0 / 0 / 0+1 / 1 / 1 /$ & cic & 0 \\
\hline Prolates & VIII-IX+10? & $I I I+6 ?$ & $24-25(10-11+14)$ & $?$ & $?$ & cte & 1 \\
\hline Proserranus & $I X-X+10$ & III+? & $24-25(10+14-15)$ & $2(9-10)$ & $?$ & cte & $?$ \\
\hline Eoserranus & $?$ & $?$ & $?$ & $?$ & $?$ & cic & $?$ \\
\hline Bannikovperca & $?$ & $I I I+9$ & $17 ?(2 ?+15)$ & $?$ & $?$ & cic & 0 \\
\hline Johnsonperca & IV?+? & - & $9 ?(9 ?+?)$ & $6 ?(4-9 ?)$ & $/ 0+0 / 0+1 / 1 / 1 /$ & cic & 0 \\
\hline Jimtylerius & $x+9$ & III+7? & $24(10+14)$ & $5(6-10)$ & $/ 0+0 / 0+2 / 1+1 /$ & cic & 0 \\
\hline Saldenioicthys & $\mathrm{VI} ?+?$ & III+? & $20 ?(6 ?+14)$ & - & $?$ & cte & 0 \\
\hline Indiaicthys & $\mathrm{VIII+8}$ & $\mathrm{III+10}$ & $24(10+14)$ & $2(9-10)$ & $\begin{array}{c}0 / 0+0+2 / 1+1 / ? \\
\text { or } \\
0+0 / 0+2 / 1+1 / ? \\
\text { or } \\
0 / 0 / 0+2 / 1+1 / ?\end{array}$ & cte & 1 \\
\hline Amphiperca & $|X-X|+10-12$ & $I I I+8-9$ & $27-28(10-11+16-17)$ & $5 ?$ & $0 / 0 / 0+2 / 1+1 /$ & cte & $?$ \\
\hline Palaeoperca & VIII + I, 8-9 & III + 6-8 & $23(10+13)$ & $7 ?$ & $?$ & cte & $?$ \\
\hline Rhenanoperca & $|X-X|+9-10$ & $I I I+7-9$ & $24-25(9-11 ?+14-15$ & $7 ?$ & $0 / 0 / 0+2 / 1+1 /$ & cte & 1 \\
\hline IGM 4550 & $I X+10$ & $I I I+7$ & $24(10+14)$ & $3(8-10)$ & $0 / 0 / 0+2 / 1+1 /$ & cte & 1 \\
\hline
\end{tabular}

described Nardoichthys francisci Sorbini and Bannikov, 1991, from the Campanian-Maastrichtian marine deposits near Nardo, Italy; Bannikovperca apula Taverne, 2010; Johnsonperca annavaccarii Taverne, 2010; and Zorzinperca weverberghi Taverne, 2010. Some additional fossils described by Arratia et al. (2004), Indiaichthys bamanborensis and "Percomorpha indet.", have been collected from the Late Cretaceous-Paleocene deposits of the Deccan Plateau, near Bamanbor, India. Bannikov and Carnevale (2007) described a perciform species from the Eocene of Monte Bolca, Italy, as Jimtylerius temnopterusa (including some specimens previously described as Dules temnopterus (Agassiz, 1836), and considered as belonging to the family Scianidae). Finally, the incomplete perciform specimens collected in the Maastrichtian deposits of Saldeño, Province of Mendoza, Argentina, were identified as Saldenioicthhys remotus López-Arbarello et al., 2003, and "Undeterminated Acanthomorpa." Other three Middle Eocene perciformes are known from the freshwater deposits of
Messel, including Amphiperca multiformes Weitzel, 1933; Palaeoperca proxima Micklich, 1978; and Rhenanoperca minuta Gaudant and Micklich, 1990.

Table 1 compares all fossils referred above and specimen IGM 4550. In many cases, the anatomy of these fossils is only partially known; however, it is noticeable that IGM 4550 resembles Prolates, Proserranus, Jimtylerius, Indiaichthys, and Rhenanoperca in that they all exhibit ctenoid scales, 24 total vertebrae (including 10 abdominal and 14 caudal, a condition considered as primitive among "percoids"; e.g., Gosline 1968, 1971; Johnson, 1984; Bannikov and Carnevale, 2009). In Palaeoperca the dorsal fin include two lobes clearly separated from each other; hence, this German species is clearly different from IGM 4550 that has a continuous dorsal fin. Among these fishes, IGM 4550, Rhenanoperca, Prolates, and Proserranus share the same dorsal fin pattern, nine spines and 10 rays forming a single and continuous dorsal fin. Although in the last two nominal genera the 


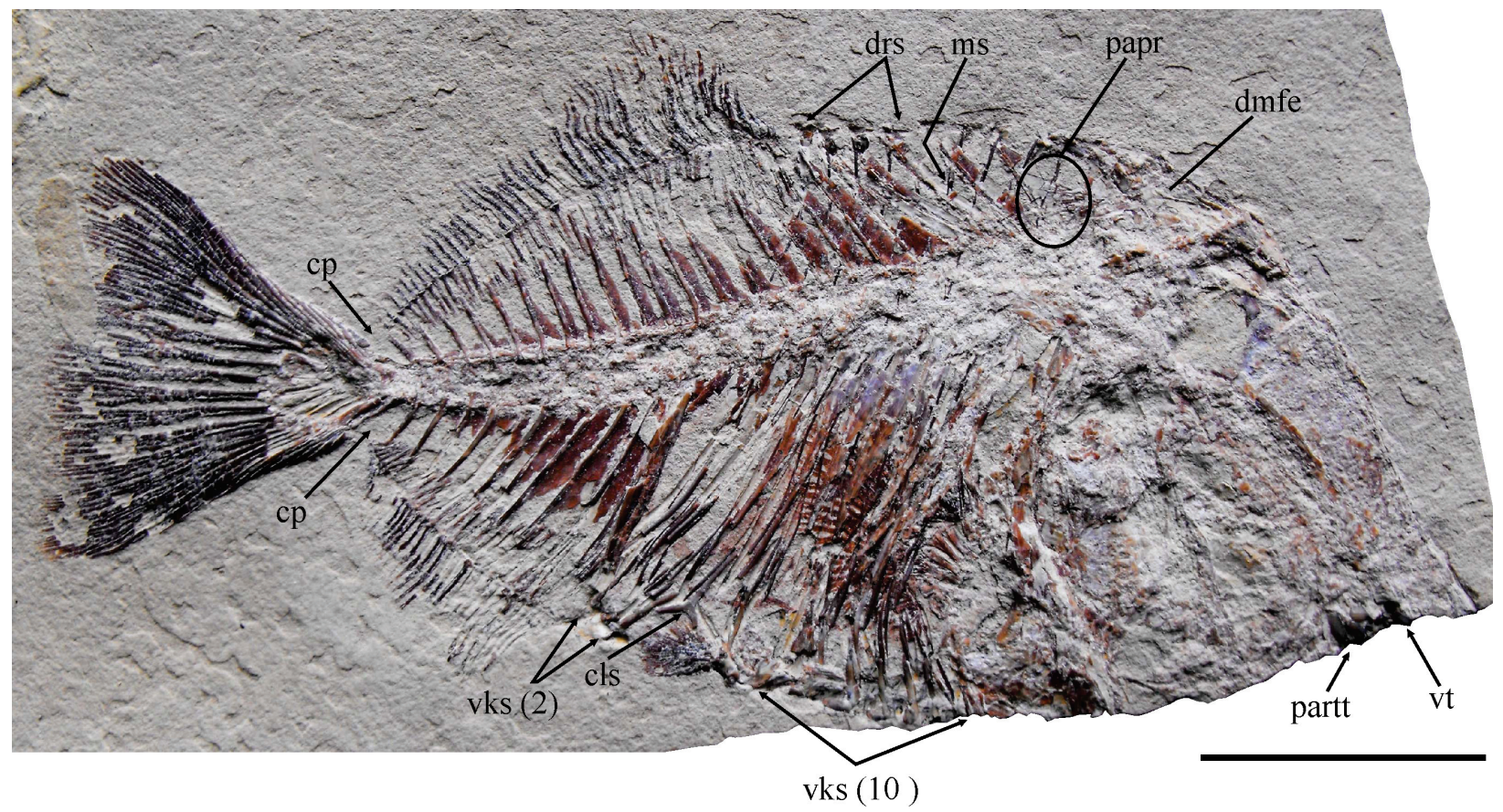

FIGURE 8. Specimen IGM 4551, Pycnodus sp. from the Paleocene marine strata of División del Norte quarry, Municipality of Palenque, Chiapas, Mexico. Scale bar equals $20 \mathrm{~mm}$. Abbreviations: cls, cloacal scale; $\mathrm{cp}$, caudal peduncle; dmfe, dermocranial fenestra; drs, dorsal ridge scales; ms, modified bar-like scales; papr, parietal process; partt, prearticular teeth; vks, ventral keel scales; vt, vomer teeth.

composition of the anal fin remains uncertain; the pattern III+7 (spine + soft rays) found in the anal fin of IGM 4550 is into the range of Rhenanoperca (III+7-9).

Although the predorsal formula of IGM 4550 $(0 / 0 / 0+2 / 1+1 /)$ has been previously documented in Prolates, Proserranus, Amphiperca, Palaeoperca, Rhenanoperca, and probably in Indiaichthys; the presence of one premaxilla is documented only IGM 4550, Prolates, Rhenanoperca, and Indiaichthys. Additionally, it is noteworthy the fact that the number of abdominal vertebrae with parapophysis is still an undocumented characteristic in some of the fossils here included. In this context, IGM 4550 shows an attribute never documented in any of the other fossils, only the last three abdominal vertebra (8-10) presents a parapophysis; in contrast, this structure of the bdominal centra is developed in two centra of Indiaichthtys and Amphiperca (Micklich, 2008, figures 1 and 2) and at least in five of the other fossil fishes previously discussed in this work (Table 1). Despite this observation, a full anatomical analysis of IGM 4550 and similar taxa (including Indiaicthys, Rhenanoperca, Amphiperca, and Palaeoperca) is required before naming a possibly new species.
Order PYCNODONTIFORMES Berg, 1937

Family PYCNODONTIDAE sensu Nursall, 1996

Genus PYCNODUS Agassiz, 1833

Pycnodus sp.

Referred Material. IGM 4551, almost complete specimen from the División del Norte quarry (i.e., Locality-IGM 3869) preserved in part (Figure 8) and counterpart. This specimen lacks the tips of the lower and upper jaws; its estimated standard length is $79 \mathrm{~mm}$. IHNFG-4890, complete specimen from the Belisario Domínguez quarry; its estimated standard length is $90 \mathrm{~mm}$.

Remarks and comparison. These specimens display an assortment of diagnostic characteristics for the order Pycnodontiformes as previously recorded by numerous authors (e.g., Nursall, 1996; Machado and Brito, 2006) including the presence of molariform teeth arranged in rows on the vomer and prearticular bones and differentiated cloacal and contour ridge scales (here named dorsal ridge scales and ventral keel scales) (Figure 8). Additionally, the referred specimens show a parietal peniculus-like process, an unusual structure and a diagnostic characteristic of the family Pycnodontidae sensu Poyato-Ariza and Wenz (2002).

Poyato-Ariza and Wenz (2002) erected the Pycnodontinae subfamily, a group within the Pyc- 
nodontidae family, to include the Pycnodus and Oropycnodus genera. Although Kriwet (2005) suggested and alternative hypothesis in which these fishes are not sister taxa, new discoveries support the idea that this is a natural and diverse group which also includes three Italian monospecific genera: Tergestinia Capasso, 2000, from the Paleocene deposit of Trebiciano; Pseudopycnodus Taverne, 2003, from Campanian-Maastrichtian strata of Nardo; and Polazzodus Poyato-Ariza, 2010, collected in Turonian-early Senonian outcrops at Polazzo. In addition, the Portuguese fish Silvienodus Poyato-Ariza, 2013, from Cenomanian deposits at Laveiras, might also belong in this subfamily.

Among Pycnodontiformes, the subfamilies Pycnodontinae and Nursallinae share the occurrence of a bifid scale above the cloacal opening (Poyato-Ariza and Wenz, 2002, characteristic 104(1)); this peculiar scale is present in specimens IGM 4551 and IHNFG-4890. Pycnodontines also are distinctive and well characterized by the presence of postcephalic lacuna that leave the endocranium posteriorly exposed, incompletely ossified or reduced to bar-like structures scales in their dorsal lateral abdominal region, and a number of 10 to 15 ventral keel scales (Taverne and Capasso, 2012; Poyato-Ariza, 2013, p. 99). The specimens referred here are considered to be members of Pycnodontinae because, in addition to the occurrence of the bifid scale mentioned above, they show the typical bar-like scales in the anterior dorsal area of the trunk and approximately 12 ventral keel scales (10 in front of the cloaca and 2 behind).

At present, it is difficult to support the inclusion of Silvienodus in the Pycnodontinae subfamily because of ambiguous data published; its author suggested the lack of postcephalic lacuna in this fish but later he confirmed its presence (PoyatoAriza, 2013, p. 94, 99). Oropycnodus and Pycnodus share the presence of a well-defined dermocranial fenestra, a lateral opening in the dermocranium bordered by the frontal, parietal, dermal supraoccipital bones (referred to as temporal fenestra by Nursall (1996) and Taverne and Capasso (2012)). Although this fenestra is also present in other pycnodontiforms, among Pycnodontines it is exclusively present in Oropycnodus and Pycnodus, as well as in the División del Norte and Belisario Domínguez specimens referred here.

Oropycnodus differs from Pycnodus and Mexican specimens IGM 4551 and IHNFG -4890 because the bifid scale in its cloaca is bordered by modified comma-shaped scales, its caudal pedun- cle is not differentiated (there are less than three neural and haemal spines between the beginning of caudal endoskeleton and the end of anal and dorsal fins), and it exhibits a post-cloacal notch (formed between the two postcloacal ventral keel scales). On the other hand, the genus Pycnodus and the specimens referred here do not have such comma-shaped scales in the cloaca, their caudal peduncle is well differentiated, and they do not exhibit any post-cloacal notch (see Poyato-Ariza and Wenz, 2002, characters 7, 71, 104 and 105). Hence, we conclude that the División del Norte and Belisario Domínguez specimens referred here belong to the genus Pycnodus.

Numerous Cretaceous-Eocene nominal species of Pycnodus have been described based mainly on extremely incomplete specimens. However, Poyato-Ariza (2013) has restricted the genus to only one species from the Eocene deposits of Monte Bolca, Pycnodus apodus. The Mexican specimens described above show characteristics that suggest they are representatives of a new species of this genus. In comparison to previous anatomical data of Pycnodus apodus (Poyato-Ariza and Wenz, 2002), these Mexican fishes show a greater number of total and post-cloacal (10) and ventral keel scales (2) versus 7 and 1 scales, respectively, found in $P$. apodus. Also, the División del Norte and Belisario Domínguez specimens show less dorsal and anal pterygiophores or axonosts (4142 and 32, respectively) than in $P$. apodus (58 and 45) and a large or regular-sized last neural spine that clearly differs from the vestigial condition of this structure present in $P$. apodus. Regardless the above observation, a more complete anatomical analysis of these Mexican fishes is required before naming a possibly new species.

The occurrence of Pycnodus in Mexico confirms the presence of Pycnodontinae fishes in North America, evidencing a wide marine distribution of this subfamily (see Alvarado-Ortega et al., 2006). The body shape of pycnodontiforms suggests that these fishes were not competent pelagic swimmers. This observation, along with a restricted temporal occurrence of the known members of this group: División del Norte and Belisario Domínguez Pycnodus sp. (Paleocene, North America, Mexico), Pycnodus (Eocene, Europe, Italy), and Oropycnodus (Paleocene, Europe, France), suggest that this crown group of the subfamily Pycnodontinae has a long evolutionary history that could be traced back to at least the middle Cretaceous, when continents derived from Pangea were not yet significantly apart from each other. 


\section{Other Fishes}

The present paper is a mere overview of the fish diversity so far collected from the Paleocene marine strata of the División del Norte and Belisario Dominguez quarries. Some other fishes not presented in this work include specimens under current preparation, awaiting taxonomic identification, or part of other descriptive studies still in progress. Although the fish diversity from these localities has not been completely determined yet, the authors believe that there may be other possible pycnodontiforms, at least another clupeid fish, another possible serranid perciform, characiforms that may belong to the family Erythrinidae, a specimen related to Syngnathiformes, as well as fishes of both major groups of the orders Gonorynchiformes, Gonorynchidae and Chanidae.

\section{DISCUSSION AND CONCLUSIONS}

Even though several other aspects are necessary to consider in a more comprehensive study on the diversity and taxonomic identity of the fossil fishes present in the División del Norte and the Belisario Domínguez quarries, three features of these Mexican localities and their fossils can presently be discussed. On the one hand, their Paleocene age, dated back on $63 \mathrm{my}$, offers a rare opportunity to examine the effects on marine life, particularly on fishes, produced by the Mass Extinction Event of the Cretaceous-Paleogene boundary (MEE-K/P). Moreover, the División del Norte and the Belisario Domínguez quarries are geographically adjacent (approximately $500 \mathrm{~km}$ ) to Chicxulub, the crater formed by the asteroid impact generally considered the main reason for the MEEK/P.

Finally, it is noteworthy that the fossils discussed in this manuscript represent a unique Paleocene fish assemblage that contains taxa whose relatives are found in a number of merely younger Paleogene localities around the world. The current ideas on the diversification and extinction processes experienced by the fishes through the MEE-K/P are based on the fossil record patterns observed in relatively few localities, which are somewhat temporarily far from the $\mathrm{K} / \mathrm{T}$ boundary. Although varied studies have attempted to document these processes (e.g., Bannikov and Parin, 1997; Weems, 1998; Friedman, 2010), at present, no comparison in fish diversity is altered in duplicate for the Lagerstätten effect as previously noted by Patterson (1993) and Patterson and Smith (1987). MacLeod et al. (1997) identified two peaks of teleost diversity on both sides of the K/P boundary. Undoubtedly, both peaks are associated with the rich fish diversity found in two kinds of localities of extraordinary preservation: the Campanian localities (e.g., Sedenhorst, in Westphalia) and the Eocene localities (e.g., Monte Bolca, Italy; the London Clay of the Anglo-Paris Basin; Green River, USA), whose datings are either older or younger than 71 and 54 my, respectively, away from the K/P boundary dated back to $66.236 \pm 0.06$ my (Husson et al., 2011). Thus, the age of 63 my of these Mexican fish localities (Cuevas-García and AlvaradoOrtega, 2009), makes them the closest scenario to the $\mathrm{K} / \mathrm{T}$ boundary (at least in North America) at present. Therefore, the study of the División del Norte and the Belisario Domínguez quarries is necessary to have a more precise understanding of the fish diversity change through the MEE-K/P (Figure 9).

MacLeod et al., (1997) recorded the MEE-K/P effect at a family level, showing a minimal-devastating effect on fishes, demonstrating that their survival rates are high throughout the K/P boundary, e.g. $83 \%$ for chondychthyes and approximately 93 $\%$ for osteoichthyes, particularly teleosts. More recently, Cavin (2001) set the survival rate of teleostean families slightly below that of the chondychthyans (81\%).

According to Cavin and Martin (1995) and Cavin (2001), the MEE-KP on teleosts was considerably greater on pelagic groups at a family level than in benthic, coastal, and continental taxa. However, and despite the marine origin of the Division del Norte and the Belisario Domínguez strata, chondrichthyians have not yet been collected from these localities, and osteichthyians dominate their ichthyofauna.

The taxonomic designation of the Mexican Paleocene fishes presented here may help resolve some problematic phylogenetic relationships, particularly those within the Cretaceous-CenozoicRecent eels and those in the basal Percoids "serranids", minimizing the Lazarus effect on the teleost survivors of the MEE-K/P (Cavin and Martin, 1995; Cavin, 2001). Moreover, the data presented here have contributed to recognize an amphi-Pacific distribution of pycnodontids during the Paleogene. In addition, their survival through the MEE-K/P will undoubtedly affect the rates calculated by the authors cited above.

Osteoglossiformes are considered a primarily freshwater group with few brackish-water members, as well as extremely scarce fossils found in marine deposits (Woodward, 1901; Bonde, 2008). 


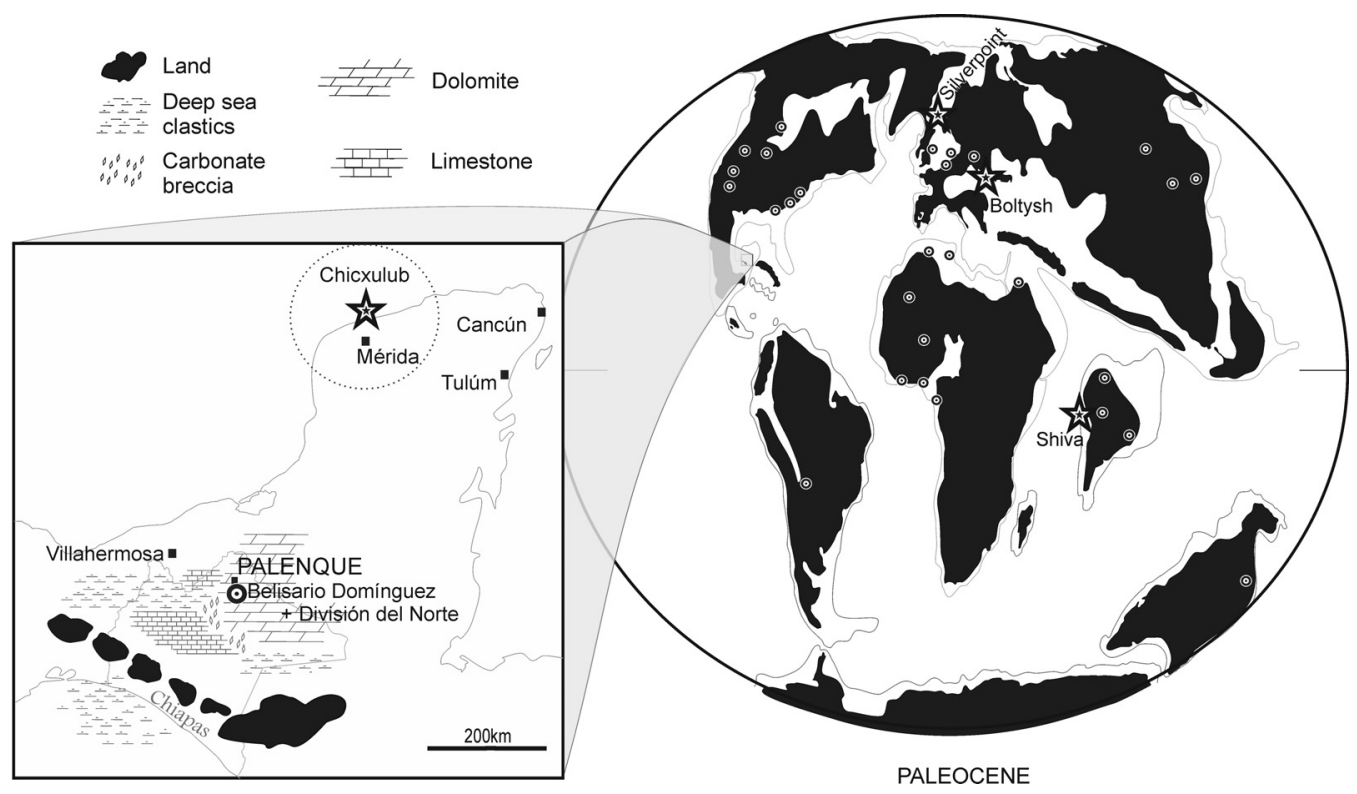

FIGURE 9. Paleocene map showing the distribution of localities with osteichthyan fossils (based on Weems, 1998; Arratia et al., 2004) (black and white concentric circles), the distribution of the craters of the multiple asteroid impacts in the mass extinction event of the Cretaceous-Tertiary boundary (black and white concentric stars), and the distribution of land and main marine sedimentary domains around Palenque (based on Meneses-Rocha, 2001, figure 12e).

Therefore, the occurrence of the osteoglossin Phareodus in the marine deposits of the División del Norte quarry is of major importance to the fossil record of this group. This finding extends the temporal distribution of Phareodus to the early Paleocene, complementing the dispersal of osteoglossins in a geographical position never expected before. The above suggests a more complex Paleocene-Eocene intra-continental evolution and distribution of the North American osteoglossins, including their marine occurrence in the southern end of this subcontinent.

Recently, Chatterjee et al., (2006) discussed the multiple asteroid impacts on Earth and their possible effects on the MEE-K/P. The first to be identified and the most popular of these impacts is the Chicxulub, which formed a $120 \mathrm{~km}$ diameter crater on the sea floor of the Yucatan Peninsula, Mexico, 300,000 years before the K/P Mass Extinction started (Hildebrand et al., 1991; Keller et al., 2004). Other two K/T impacts which occurred on the sea floor vicinities left behind the small Silverpit Crater in the North Sea (20 km diameter) (Stewart and Allen, 2002) and the comparatively larger Shiva Crater (500 km diameter), near the western border of India (Chatterjee and Rudra, 1996). Only one of these impacts occurred in a continental surface, leaving the $24 \mathrm{Km}$ wide crater Boltysh, formed in a Ukraine lake (Kelley and Gurov, 2002). Due to its massive size and devas- tating energy and effects on Earth 66 my ago, the Shiva impact might as well have been the ultimate trigger to the MEE-KP (Chatterjee et al., 2006).

A comparison of the Mexican ichthyofaunas herein described and those from the Indian localities associated to both the Deccan volcanic activity and the Shiva Crater is compulsory. The need of this comparison lies on the fact that such localities are close to the two largest craters linked to the MEE-K/P (Figure 9). The age of some Indian localities might be controversial after more than 40 years of research since they might have formed an upper Maastrichthian-early Eocene collage (Arratia et al, 2004). Despite the debate above, the Indian fishes from these sites show noteworthy taxonomic similarities with the Paleocene ichthyofauna from División del Norte and Belisario Domínguez, near Palenque. In all three localities, the genus Pycnodus, and a number or "serranids" and "clupeids" are present. Although the Indian percomorphs seem to be represented by prostolepids, there are four possible "serranids" from Palenque that require to be described. The record of gars or lepisosteids described in the Indian localities was not found in its Palenque counterpart. However, the record of eels in Palenque is a distinctive feature of the latter.

Although the fish diversity so far collected from the División del Norte and the Belisario Domínguez quarries may be considered scarce, it 
should not be forgotten that these are new sites, still not fully explored. Therefore, their richness might be increased with a more intense collection effort. At present, such efforts have been limited by an inaccessibility of their location (in the middle of the jungle), and a difficulty in working there all year, because field trips are limited to the dry season, from February to May.

\section{ACKNOWLEDGMENTS}

The fulfillment of this paper was made possible by the effort of local people of Palenque, who helped us as guides during the field works, a special mention goes to D.M. Hurtado and sons as well as to A. Montejo and family. Our collegues Dr. A. Cristin-Ponciano, and G. Velasquillo helped us in the interpretation of the geology of Palenque. The paleontological prospection and fossil collecting was also supported by our students $F$. Riquelme, M.J. Nuñez-Utrilla, and I.R. EspinozaEncinas. We also thank our friends L.P. Machado and J.M. Contreras-Almazán for the photos published here. Since 2008, the financial support was partially provided by INAH, through a grant to our project "Estudio arqueológico y paleontológico de los fósiles marinos que proceden del sitio de Palenque, Chiapas," and by UNAM trough the projects PAPIIT IN225008, IN106011, and IN207314. Additional support to GSL and MPMD was provided by CONACyT Master's degree fellowship program.

\section{REFERENCES}

Agassiz, J.L.R. 1833-1844. Recherches sur les poissons fossiles. 5 volumes, Neuchâtel et Soleure, Petitpierre.

Alaniz-Galvan, A. 2011. Primer registro de perciformes fósiles paleocénicos de Palenque, Chiapas, México. Unpublished Bachelor's degree Thesis, Facultad de Ciencias, Universidad Nacional Autónoma de México, D.F., Mexico.

Alvarado-Ortega, J. 2014. Ancient herring from the Tlayúa Quarry (Cretaceous, Albian) near Tepexi de Rodíguez, Puebla State, central Mexico, closing the gap in the early diversification of Clupeomorpha. Cretaceous Research, 50:171-186.

Alvarado-Ortega, J., Espinosa-Arrubarrena, L., BlancoPiñón, A., Vega, F., Benammi, M., and Briggs, D.G. 2007. Exceptional preservation of the soft tissues in fishes from Tlayúa Quarry, Central Mexico. Palaios, 22:682-685.

Alvarado-Ortega, J., González-Rodríguez, K.A., BlacoPiñón, A., Espinosa-Arrubarrena, L., and OvallesDamián, E. 2006. Mesozoic Osteichthyans of Mexico, p. 169-207. In Vega, F.J., Nyborg, T.G., Perrilliat,
M.C., Montellano-Ballesteros, M., Cevallos-Ferriz, S.R.S., and Quiroz-Barroso, S.A. (eds.), Studies on Mexican Paleontology. Topics on Geobiology 24. Springer, The Netherlands.

Alvarado-Ortega, J. and Than-Marchese, B.A. 2012. A Cenomanian aipiochthyoid fish (Teleostei, Acantomorpha) from America, Zoqueichthys carolinae gen. and sp. nov. from El Chango quarry (Cintalapa Member, Sierra Madre Formation), Chiapas, Mexico. Revista Mexiana de Ciencias Geológicas, 29:735748.

Arratia, G., López-Arbarello, A., Prassad, G.V.R., and Kriwet, J. 2004. Late Cretaceous-Paleocene percomorphs (Teleostei) from India -early radiation of perciformes-, p. 635-663. In Arratia, G., Wilson, M.V.H., and Cloutier, R., (eds.), Recent Advances in the Origin and Early Radiation of Vertebrates. Verlag Dr. Friedrich Pfeil, Germany.

Bannikov, A.F. and Carnevale, G. 2007. The Eocene «Dules» temnopterus Agassiz, 1836 from Monte Bolca, and problem of classifying fossil percoid fishes. Palaeontographia Italica, 91:69-84.

Bannikov, A.F. and Carnevale, G. 2009. A new percoid fish from the Eocene of Monte Bolca, Italy: Hendrixella grandei gen. \& sp nov. Swiss Journal of Geosciences, 102:481-488.

Bannikov, A.F. and Parin, N.N. 1997. The list of marine fishes from Cenozoic (Upper Paleocene-Middle Miocene) localities in southern European Russia and adjacent countries. Journal of Ichthyology, 37:149161.

Belouze, A., Gayet, M., and Atallah, C. 2003. Les premiers Anguilliformes. I. Révision des genres cénomaniens Anguillavus Hay, 1903 et Luenchelys nov. gen. Geobios, 36:241-273.

Berg, L.S. 1937. A classification of fish-like vertebrates. Bulletin de l'Académie des Sciences de I'URSS, Classe des Sciences mathématiques et naturelles, 4:1277-1280.

Bleeker, P. 1859. Enumeratio speciorum piscium hujusque in Archipelago Indico observatarum, adjectis habitationibus citationibusque, ubi descriptions earum recentiores reperiuntur, nec non species Musei Bleekeriani Bengalensibus, Japonicis, Capensibus Tasmanicisque. Acta Societatis Scientarium IndoNeerlandicae, 6:1-276+XXXVI.

Blot, J. 1984. Actinopterygii. Ordre des Scorpaeniformes? Famille des Pterygocephalidae Blot 1980. Studi e Ricerche sui Giacimenti Terziari di Bolca, 4:265-305.

Bonaparte, C.L. 1832. Saggio d'una distribuzione metodica degli animali vertebrati. Giornale Arcadico di Scienze Lettere ed Arti, 52:155-189.

Bonde, N. 2008. Osteoglossomorphs of the marine Lower Eocene of Demnark with remarks on other Eocene taxa and their importance for palaeobiogeography, p. 253-310. In Cavin, L., Longbottom, A., and Richter, M. (eds.), Fishes and the Break-up of Pan- 
gaea. Special Publications 295, Geological Society, London.

Capasso, L. 2000. Tergestinia sorbinii gen. nov., sp. nov., del Paleocene inferiore di Trebiciano, Trieste (Pisces, Pycnodontiformes). Atti del museo Civico de Storia Natutrale di Trieste, 48:261-289.

Casier, E. 1967. Le Landénien de Dormaal (Brabant) et sa faune ichthyologique. Institut Royal des Sciences Naturelles de Belgique, Mémoires, 156:1-66.

Cavin, L. 2001. Effects of the Cretaceous-Tertiary boundary event on bony Fishes, p. 141-158. In Buffetaut , E. and Koeberl, C. (eds.), Geological and Biological Effects of Impact Events. Springer Verlag, Berlin.

Cavin, L. and Martin, M. 1995. Les Actinoptérygiens et la limite Crétacé-Tertaire. Giobios Special Memoirs, 19:183-188.

Chatterjee, S. and Rudra, D.K. 1996. KT events in India: impact, volcanism and dinosaur extinction. Memoirs of the Queensland Museum, 39:489-532.

Chatterjee, S., Guven N., Yoshinobu, A., and Donofrio, R. 2006. Shiva structure: a possible KT boundary impact crater on the western shelf of India. Natural Science Research Laboratory, Special Publications of Museum of Texas Tech University, 50:1-39.

Chen, J.N., López, J.A., Lavoué, S., Miya, M., and Chen, W.J. 2014. Phylogeny of the Elopomorpha (Teleostei): Evidence from six nuclear and mitochondrial markers. Molecular phylogenetics and evolution, 70:152-161.

Cope, E.D. 1871. On the fishes of the Tertiary shales of Green River, Wyoming Territory, p. 425-431. In Hayden, F.V. (ed.), Preliminary report of the United States Geological Survey of Wyoming. Government Printing Office, Washington.

Cope, E.D. 1877. A contribution to the knowledge of the ichthyological fauna of the Green River shales. Bulletin of the United States Geological and Geographical Survey of the Territories, 3:807-819.

Cuevas-García, M. 2008. Paisaje Paleontológico en Palenque, p. 483-490. In Laporte J.P., Arroyo, B., and Mejía, H.E. (eds.), XXI Simposio de Investigaciones Arqueológicas en Guatemala, volumen 1. Museo Nacional de Arqueología y Etnología, Guatemala.

Cuevas-García, M. and Alvarado-Ortega, J. 2009. Estudio arqueológico y paleontológico de los fósiles marinos que proceden del sitio de Palenque, Chiapas. Informe de la primera temporada de campo 2008, Instituto Nacional de Antropología e Historia, Mexico.

Cuvier, G. 1817. Le Règne animal distributé d’après son organisation, pour servir de base à l'historie naturelle des animaux et d'introduction à l'anatomie comparée, Volume 2. Chez Déterville, Paris.

Daniltshenko, P.G. 1964. Superorder Teleostei -The Ray Finned Fishes-, p. 369-472. In Obruchev D.V. (ed.), Osnovy paleontologii, Beschelyustnye ryby (Principles of Paleontology, Agnatha Fishes). Nauka, Moscow.
Davis, J.W. 1890. On the fossil fishes of the Cretaceous formations of Scandinavia. Science Transactions of Royal Dublin Society, 4:363-434.

Fernández, M.A. 1991. Las ofrendas del Templo del Sol y de la Cruz Enramada. Temporada de trabajos en la zona arqueológica de Palenque, Chiapas, p. 239298. In García-Moll, R. (ed.), Palenque 1926-1945: Antologías. Serie Arqueología, Instituto Nacional de Antropología e Historia, México.

Forey, P., Littlewood, D.T., Ritchie, P., and Meyer, A. 1996. Interrelationships of elopomorph fishes, $p$. 175-186. In Stiassny, M.L.J., Parenti, L.R., and Johnson, J.D. (eds.), Interrelationships of fishes. Academic Press, New York.

Forey, P., Yi, L., Patterson, C., and Davies, C.E. 2003. Fossil fishes from the Cenomanian (Upper Cretaceous) of Namoura, Lebanon. Journal of Systematic Palaeontology, 1:227-330.

Friedman, M. 2010. Explosive morphological diversification of spiny-finned teleost fishes in the aftermath of the end-Cretaceous extinction. Proceedings of the Royal Society, Serie B, Biological Sciences, 277:1675-1683.

Gaudant, J. 1991. Paleontology and history of clupeoid fishes, p. 32-44. In Hoestlandt, H. (ed.), The freshwater fishes of Europe. Aula Verlag, Wiesbaden, Germany.

Gaudant, J. and Micklich, N. 1990. Rhenanoperca minuta nov. gen., nov. sp., ein neuer Percoide (Pisces, Perciformes) aus der Messel-Formation (Mittel-Eozän,

Unteres Geiseltalium). Paläontologische Zeitschrift, 64:269286.

González, A.J. 1965. Informe Geológico del Área Chanal-Ocosingo, Chiapas. Informe Geológico no. 504:Petróleos Mexicanos, Zona Sur, 4-5, México.

González-Cruz, A. 1993. Trabajos Arqueológicos en Palenque, Chiapas. Informe, Volumen VII, Serie Informes de Campo 6. Instituto Nacional de Antropología e Historia, México.

Goodrich, E.S. 1909. Vertebrata Craniata, Part IX (First Fascicle: Cyclostomes and Fishes), p. XVI+518. In Lankester, R. (ed.), A Treatise on Zoology. Adam and Charles Black, London.

Gosline, W.A. 1968. The suborders of perciform fishes. Proceedings of the United States National Museum, 124(3647):1-78.

Gosline, W.A. 1971. Functional morphology and classification of teleostean fishes. University of Hawaii Press, Honolulu.

Grande, L. 1985. Recent and fossil clupeomorph fishes with materials for revision of the subgroups of clupeoids. Bulletin of American Museum Natural History, 181:231-372.

Greenwood, P.H., Rosen, D.E., Weitzman, S.H., and Myers, G.S. 1966. Phyletic studies of teleostean fishes, with a provisional classification of living forms. Bulletin of American Museum Natural History, 131:339-456. 
Hildebrand, A.R., Penfield, G.T., Kring, D.A., Pilkington, M., Camargo, Z.A, Jacobsen, S.B., and Boynton, W.V. 1991. Chicxulub Crater: A possible Cretaceous/ Tertiary boundary impact crater on the Yucatán Peninsula, Mexico. Geology, 19:867-871.

Hills, E.S. 1934. Tertiary fresh water fishes from southern Queensland. Memoirs of the Queensland Museum, 10:157-174.

Hilton, E.J. 2003. Comparative osteology and phylogenetic systematics of fossil and living bony-tongue fishes (Actinopterygii, Teleostei, Osteoglossomorpha). Zoological Journal of the Linnean Society, 137:1-100.

Husson, D., Galbrun, B., Laskar, J., Hinnov, L.A., Thibault, N., Gardin, S., and Locklair, R.E. 2011. Astronomical calibration of the Maastrichtian (late Cretaceous). Earth and Planetary Science Letters, 305:328-340.

Inoue, J.G., Miya, M., Tsukamoto, K., and Nishida, M. 2001. Complete mitochondrial DNA sequence of the Japanese anchovy Engraulis japonicas. Fish Science, 67:828-835.

Johnson, G.D. 1983. Niphon spinosus: A primitive epinepheline serranids, with comments on the monophyly and interrelationships of the Serranidae. Copeia, 1998:777-787.

Johnson, G.D. 1984. Percoidei: Development and relationships, p. 484-498. In Moser, H.G., Richards, W.J., Cohen, D.M., Fahay, M.P., Kendall, A.W., and Richardson, S.L. (eds.), Ontogeny and Systematics of Fishes. American Society of Ichthyologists and Herpetologists, Special Publication No. 1, Lawrence, Kansas.

Johnson, G.D., Ida, H., Sakaue, J., Sado, T., Asahida, T., and Miya, M. 2011. A 'living fossil' eel (Anguilliformes: Protoanguillidae, fam. nov.) from an undersea cave in Palau. Proceedings of the Royal Society B: Biological Sciences, 10:1-10.

Johnson, G.D. and Patterson, C. 1993. Percomorph phylogeny: A survey of acantomorphs and new proposed. Bulletin of Marine Science, 52:554-626.

Keller, G., Adatte, T., Stinnesbeck, W., Rebolledo-Vieyra, M., Urrutia-Fucugauchi, J., and Stüben, D. 2004. Chicxulub impact predates the K-T boundary mass extinction. Proceedings of the National Academy of Sciences of the United States of America, 101:37533758.

Kelley, P.S. and Gurov, E. 2002. Boltysh, another endCretaceous impact. Meteoritics and Planetary Science, 37:1031-1043.

Kendall, A.W. 1976. Predorsal and associated bones in Serranids and Grammistid fishes. Bulletin of Marine Science, 26:585-592.

Kriwet, J. 2005. A comprehensive study of the skull and dentition of pycnodont fishes. Zitteliana, A45:135188.

Leidy, J. 1873. Notice of remains of fishes in the Bridger Tertiary Formation of Wyoming. Proceedings of the
Academy of Natural Sciences of Philadelphia, 25:9799.

Li, G.-Q., Wilson, M.V.H., and Grande, L. 1997. Review of Eohiodon (Teleostei: Osteoglossomorpha) from the western North America, with a phylogenetic reassessment of Hiodontidae. Journal of Paleontology, 71:1109-1124.

López-Arbarello, A., Arratia, G., and Tunik, A. 2003. Saldenioicthhys remotus gen. et. sp. nov. (Teleostei, perciformes) and other acantomorph remains from Maastrichtian Saldeño Formation Mendoza, Argentina. Mitteilungen Aus Dem Museum Fuer Naturkunde in Berlin, 6:161-172.

López Bravo, R., López Mejía, J., and Venegas Durán, B. 2003. Entre el Motiepá y el Picota: la primera temporada del Proyecto Crecimiento Urbano de la antigua ciudad de Palenque. Lakamha', 2(9):10-15.

Machado, L. and Brito, P.M. 2006. The new genus Potiguara (Actinopterygii: Pycnodontiformes) from the Upper Cretaceous of Northeast Brazil. Journal of Vertebrate Paleontology, 26:1-6.

MacLeod, N., Rawson, P.F., Forey, P.L., Banner, F.T., Boudagher-Fadel, M.K., Bown, P.R., Burnett, J.A., Chambers, P., Culver, S., Evans, S.E., Jeffery, C., Kaminski, M.A., Lord, A.R., Milner, A.C., Milner, A.R., Morris, N., Owen, E., Rosen, B.R., Smith, A.B., Taylor, P.D., Urquhart, E., and Young, J.R. 1997. The Cretaceous-Tertiary biotic transition. Journal of the Geological Society, 154:265-292.

Meneses-Rocha, J.J. 2001. Tectonic evolution of the Ixtapa Graben, an example of Strike-Slip Basin of Southeastern Mexico: implications for Regional Petroleum Systems, p.183-216. In Bortolini, C., Buffer, R.T., and Cantú-Chapa, A.C. (eds.), The western Gulf of Mexico Basin, Tectonics, sedimentary basins and petroleum systems. Memoir 75, American Association of Petroleum Geologist. Tulsa, Oklahoma.

Micklich, N. 1978. Palaeoperca proxima, ein neuer Knochenfisch aus dem Mittel-Eozän von Messel bei Darmstadt. Senckenbergiana lethaea, 59:483-501.

Micklich, N. 1985. Biologisch-palaontologische Untersuchungen zur Fischfauna der Mes seler Olschiefer (Mittel-Eozan, Lutetium). Andrias, 4:3-171.

Micklich, N. 2008. Messel Pit -A cradle of Species?, p. 74-77. In Krempaska, Z. (ed.), 6th Meeting of the European Association of Vertebrate Paleontologists. Museum of Spiš in Spišská Nová Ves, Spišská Nová Ves, Slovak Republic.

Mullerried, F.K. 1951. Algunos fósiles marinos del Terciario Inferior y Medio de Palenque, Chiapas. Revista de la Sociedad Mexicana de Historia Natural, 12:209227.

Nelson, G.J. 1969. Infraorbital bones and their bearing on the phylogeny and geography of osteoglossomorph fishes. American Museum Novitates, 2394:137.

Nelson, G.J. 2006. Fishes of the world. John Wiley and sons, Inc., New Jersey. 
Nursall, J.R. 1996. The phylogeny of pycnodont fishes, p. 125-152. In Arratia, G. and Viohl, G. (eds.), Mesozoic Fishes -Systematics and Paleoecology-. Verlag Dr. Friedrich Pfeil, München, Germany.

Olivera-Carrasco, M.T. 1997. La arqueoictiofauna de Palenque, Chiapas, México, p. 253-278. In ArroyoCabrales, J. and Polaco, O. (coordinators), Homenaje al professor Ticúl Álvarez. Colección Científica, Instituto Nacional de Antropología e Historia, México.

Patterson, C. 1993. Osteichthyes: Teleostei, p. 621-656. In Benton, M.J. (ed.), The fossil record 2. Chapman \& Hall, London.

Patterson, C. 1964. A review of Mesozoic acanthopterigyan fishes with special reference to those of English chalk. Philosophical Transactions of the Royal Society of London. Series B, Biological Sciences, 1964:213-482.

Patterson, C. and Johnson, D.G. 1995. The intermuscular bones and ligaments of teleostean fshes. Smitshonian Contributions to Zoology, 559:1-84.

Patterson, C. and Smith, A.B. 1987. Is periodicity of mass extinctions a taxonomic artefact? Nature, 330:248-251.

Pondella, D.J., Craig, M.T., and Franck, J.P.C. 2003. The phylogeny of Paralabrax (Perciformes: Serranidae) and allied taxa inferred from partial $16 S$ and $12 S$ mitochondrial ribosomal DNA sequences. Molecular Phylogenetics and Evolution, 29:176-184.

Poyato-Ariza, F.J. 2010. Polazzodus, gen. nov., a new pycnodont fish from the Late Cretaceous of northeastern Italy. Journal of Vertebrate Paleontology, 30:650-664.

Poyato-Ariza, F.J. 2013. Sylvienodus, a new replacement genus for the Cretaceous pycnodontiform fish "Pycnodus" laveirensis. Comptes Rendus Palevol, 12:91-100.

Poyato-Ariza, F.J. and Wenz, S. 2002. A new insight onto picnodontiform fishes. Geodiversitas, 24:139248.

Priem, F. 1899. Sur les Poissons fossiles Eocènes d'Egypte et de Roumanie et rectification relative à Pseudolates heberti Gervais. Bulletin de la Société Géologique de France, 27:241-253.

Quezada, M.J.M. 1987. El Cretácico medio superior y el límite cretácico superior terciario inferior de la Sierra de Chiapas. Boletín Asicioación Mexicana de Geólogos Petroleros, 39:3-98.

Rosen, D.E. 1973. Interrelationships of higher euteleostean fishes, p. 397-513. In Greenwood, P.H., Miles, R.S., and Patterson, C. (eds.), Interrelationships of Fishes. Academic Press, London.

Ruz-Lhuillier, A. 1959. Guía oficial de Palenque. Instituto Nacional de Antropología e Historia, Cordoba, México.

Sánchez-Montes de Oca., R. 1979. Geología petrolera de la Sierra de Chiapas. Boletin de la Asociación Mexicana de Geólogos Petroleros, 31:67-97.

Santini, F., Kong, X., Sorenson, L., Carnevale, G., Mehta, R.S., and Alfaro, M.E. 2013. A multi-locus molecular timescale for the origin and diversification of eels (Order: Anguilliformes). Molecular Phylogenetics and Evolution, 69:884-894.

Sapper, K. 1894. Informe sobre la geografía física y la geológica de los estados de Chiapas y Tabasco. Boletín Agricultura, Minería e Industria de México, 3:67-97.

Sapper, K. 1896. Sobre la geografía física y la geología de la península de Yucatán. Boletín del Instituto Geológico de México, 3:1-57.

Sapper, K. 1899. Ueber gebirgsbau und Boden des noerdlichen Mittelamerika. Petermanns Mitteilungen, Ergänzungsband, volumen 127.

Servicio Geológico Mexicano (SGM) 2006a. Carta Geológico-Minera Villahermosa E15-8, escala 1:150000, 1 map. Secretaría de Economía, México.

Servicio Geológico Mexicano (SGM) 2006b. Carta Geológico-Minera Tenosique E15-9, escala 1:150000, 1 map. Secretaría de Economía, México.

Servicio Geológico Mexicano (SGM) 2014. Léxico Estratigráfico de México. Servicio Geológico de México, Secretaría de Economía, México. Available in http://www.sgm.gob.mx/ LexicoEs_ND/ default.html, accessed: September 8, 2014.

Shaw, G. 1803. General zoology or systematic natural history. Kearsley, London.

Smith, C.L. and Atz, E.H. 1969. The sexual mechanism of the reef bass, Pseudogramma bermudensis, and its implications in the classification on the Pseudogrammidae (Pisces: Perciformes). Zeitschrift für Morphologie der Tiere, 65:315-326.

Smith, L. and Craig, T.M. 2007. Casting the Percomorph Net Widely: The Importance of Broad Taxonomic Sampling in the Search for the Placement of Serranid and Percid Fishes. Copeia, 2007:35-55.

Sorbini, L. and Bannikov, A.F. 1991. The Cretaceous fishes of Nardo. II. An enigmatic spinyrayed fish. Bolletino della Societa Paleontologica Italica, 30:239249.

Steele, D.R. 1986. Contributions to the Stratigraphy of Sierra Madre Limestone (Cretaceous) of Chiapas, Part 1. Physical stratigraphy and petrology of the Cretaceous Sierra Madre Limestone, westcentral Chiapas. Universidad Nacional Autónoma de México, Instituto de Geología, Boletín, 102:1-101.

Stiassny, M.L.J. and Moore, A.J. 1992. A review of pelvic girdle of acantomorph fishes with comments on hypothesis of acantomorph intrarelationships. Zoological Journal of Linnean Society, 104:209-242.

Stewart, S.A. and Allen, P.J. 2002. A 20-km-diameter multi-ringed impact structure in the North Sea. Nature, 418(6897):520-523.

Swainson, W. 1839. The Natural History of Fishes, Amphibians, and Reptiles, or Monocardian Animals, Volumen 2. Longman, Orme, Brown, Green, Longmans, and Taylor, London.

Sychevskaya, E.K. and Prokofiev, A.M. 2004. Eels (Anguilliformes) from Later Paleocene of Turkmenistan. Journal of Ichthyology, 44:22-35. 
Taverne, L. 2003. The Cretaceous of Nardo. 15. Supplementary study of Pseudopycnodus nardoensis (Taverne, 1997) nov. gen (Actinopterygii, Halecostomi, Pyconodontiformes). Bollettino del Museo Civico di Storia Naturale di Verona Geologia Paleontologia Preistoria, 27:15-28.

Taverne, L. 2010. Les poissons crétacés de Nardò. $32^{\circ}$. Trois nouveaux Perciformes: Zorzinperca weverberghi gen. et sp. nov., Johnsonperca annavaccarii gen. et sp. nov. et Bannikovperca apula gen. et sp. nov. (Teleostei, Percomorpha). Bollettino del Museo Civico di Storia Naturale di Verona, 34:51-80.

Taverne, L. and Capasso, L. 2012. Les poissons crétacés de Nardò. $35^{\circ}$. Compléments à l'étude des halécostomes Belonostomus (Aspidorhynchiformes) et Pseudopycnodus (Pycnodontiformes). Bollettino del Museo Civico di Storia Naturale di Verona, Geologia Paleontologia Preistoria, 36:25-44.

Thomson, D.A., Findley, L.T., and Kerstitch, A.N. 1979. Reef fishes of the Sea of Cortez. Wiley, New York.

Vinson, G.L. 1962. Upper Cretaceous and tertiary stratigraphy of Guatemala. American Association of Petroleum Geologists Bulletin, 46(4):425-456.

Waite, L.E. 1986. Contributions to the Stratigraphy of Sierra Madre Limestone (Cretaceous) of Chiapas, Part 2, Biostratigraphy and paleoenvironmental analysis of the Sierra Madre Limestone (Cretaceous), Chiapas. Universidad Nacional Autónoma de México, Instituto de Geología, Boletín, 102:103-245.

Weems, R.E. 1998. Actinopterygian fish remains from the Paleocene of South Carolina, p. 147-164. In Sanders, A.E. (ed.), Paleobiology of the Williamsburg Formation (Black Mingo Group; Paleocene) of South Carolina, USA. Transactions of the American Philosophical Society, 88. American Philosophical Society, Philadelphia.
Weitzel, K. 1933. Amphiperca multiformis n. g. n. sp. und Thaumaturus intermedius n. sp., Knochenfische aus dem Mitteleozan von Messel. Notizblatt des Hessischen Vereins fur Erdkunde und der Hessischen Geologischen Landesanstalt zu Darmstadt, 5(14):8997.

Wiley, E.O. and Stewart, J.D. 1981. Urenchelys abditus, new species, the first undoubted eel (Teleostei: Anguilliformes) from the Cretaceous of North America. Journal of Vertebrate Paleontology, 1:43-47.

Wiley, E.O. and Johnson, G.D. 2009. A teleost classification based on monophyletic groups, p. 123-182. In Nelson, J.S., Schultze, H.-P., and Wilson, M.V.H. (eds.), Origin and Phylogenetic Interrelationships of Teleosts. Verlag Dr. Friedrich Pfeil, München, Germany.

Wilson, M.V.D. and Murray, A.M. 2008. Osteoglossomorpha: phylogeny, biogeography, and fossil record and the significance of key African and Chinese fossil taxa. Geological Society of London, Special Publication, 295:185-219.

Woodward, A.S. 1901. Catalogue of the Fossil Fishes in the British Museum (Natural History), Volumen 4. London, British Museum (Natural History), London.

Woodward, A.S. 1908. On some fish-remains from the Lameta beds at Dongargaon, Central Provinces. Paleontologia Indica (new series), 8:1-6.

Zhang, J.-Y. 2003. First Phareodus (Osteoglossomorpha) from China. Vertebrata PalAsiatica, 41:327-331.

Zhang, J.-Y. 2004. New fossil osteoglossomorph from Ningxia, China. Journal of Vertebrate Paleontology, 24:515-524

Zhang, J.-Y. 2006. Phylogeny of Osteoglossomorpha. Vertebrata PalAsiatica, 44:43-59. 